\title{
RESEARCH
}

Open Access

\section{Morphometric characteristics and seasonal proximity to water of the Cypriot blunt- nosed viper Macrovipera lebetina lebetina (Linnaeus, 1758)}

Daniel Jestrzemski ${ }^{*}$ (D) and Irina Kuzyakova ${ }^{2}$

\begin{abstract}
Background: The blunt-nosed viper Macrovipera lebetina (Linnaeus, 1758) is a medically important snake species in the Middle East. Its nominate subspecies Macrovipera I. lebetina is confined to Cyprus, where it is the only dangerously venomous snake species and heavily pursued. Despite the viper's large size, data on its body mass and sex-specific morphological differences are scarce. It is commonly believed that $M$. I. lebetina prefers freshwater proximity during summer. Hence, we aimed at investigating M. I. lebetina sex-specific morphological differences and its possible attraction to freshwater bodies in late summer.
\end{abstract}

Methods: Morphometric characteristics, proximity to water and conservation status of M. I. lebetina were investigated in Paphos district (Cyprus) in 2014, 2015 and 2017. Vipers were caught in different habitats, examined morphologically for metric and meristic characters, and released back into their habitat. Additionally, local people were interviewed about the conservation situation of the species.

Results: Of 38 recorded blunt-nosed vipers, morphological characteristics were collected from 34 (10 adult males, 16 adult females, eight unsexed juveniles). Rounded total length (ToL) ranged from $23.5 \mathrm{~cm}$ to $133.0 \mathrm{~cm}$ and weight between $10 \mathrm{~g}$ and $1456 \mathrm{~g}$. Adult males significantly exceeded adult females in tail length (TaL), ToL and head length $(\mathrm{HL})$. No significant sex-specific differences were found in snout-vent length (SVL), head width (HW), weight or body condition index (BCl), nor for the ratios TaL / SVL, TaL / ToL, HL / SVL or HL / HW. Adult females from late summer (2015) had a significantly lower mean BCl than those from spring (2014).

Distances of blunt-nosed vipers to the nearest water bodies (natural and artificial, respectively) did not differ significantly between spring (2014) and late summer (2015). There was also no significant difference between the distances of vipers to natural and to artificial water bodies in spring (and late summer).

Conclusions: Adult male blunt-nosed vipers exceed adult females in TaL, ToL and HL. Adult females are likely in a more vulnerable body condition in late summer than in spring. Periodic drying out of freshwater bodies in summer probably does not affect the species' occurrence. Educational workshops and habitat conservation are recommended for reducing human-viper conflict.

Keywords: Cyprus, Blunt-nosed viper, Morphology, Body condition index, Ecology, Water, Snakebite, Conservation

\footnotetext{
* Correspondence: danjetski@gmx.de

${ }^{1}$ Faculty of Forest Sciences and Forest Ecology, Department of Forest

Zoology and Forest Conservation, University of Göttingen, Büsgenweg 3,

37077 Göttingen, Germany

Full list of author information is available at the end of the article
}

(c) The Author(s). 2018 Open Access This article is distributed under the terms of the Creative Commons Attribution 4.0 International License (http://creativecommons.org/licenses/by/4.0/), which permits unrestricted use, distribution, and reproduction in any medium, provided you give appropriate credit to the original author(s) and the source, provide a link to the Creative Commons license, and indicate if changes were made. The Creative Commons Public Domain Dedication waiver (http://creativecommons.org/publicdomain/zero/1.0/) applies to the data made available in this article, unless otherwise stated. 


\section{Background}

In the Near and Middle East, true vipers (Viperinae) are of significant medical importance [1-5]. The blunt-nosed viper Macrovipera lebetina (Linnaeus, 1758) for instance has been a cause of serious snakebite accidents from Cyprus and Eastern Anatolia to Northwest India $[1,6-11]$, while its venom is of high value for drug research and development [12-16]. Macrovipera lebetina inhabits river valleys, slopes with rocky outcrops and shrubs as well as canyons, gorges, gullies, pine forests, orchards, vineyards, caves and ruins [8, 17]. This large, heavy-bodied viper is an ambush predator of small mammals and birds and is often found in agricultural areas where it feeds on rodents [8]. The nominate subspecies Macrovipera lebetina lebetina (Cypriot blunt-nosed viper) is confined to Cyprus [8]. It is the only viper species found on the island and the largest viper in the European Union, growing up to $150 \mathrm{~cm}$ in total length (ToL) [17]. Blunt-nosed vipers from the mainland (e.g., M. l. obtusa) may even exceed $200 \mathrm{~cm}$ in ToL, with the published record being $230 \mathrm{~cm}$ [18]. However, the average ToL is between 80 and $100 \mathrm{~cm}$ for most M. lebetina populations [19]. According to Ščerbak \& Böhme (2005), the largest blunt-nosed viper subspecies $(M$. l. turanica in Central Asia) reaches a ToL of $180 \mathrm{~cm}$. The maximum weight of $M$. lebetina is $2700 \mathrm{~g}$ [8]. Despite the special status of $M$. l. lebetina within the European viper fauna, little information is available on the natural history of this subspecies. Furthermore, no body mass data have been published yet on the Cypriot blunt-nosed viper. Although snake body mass (or weight) is rarely reported in the literature, it is considered the best measure of body size in life history studies and often a more useful proxy than length [20]. In this study, the snake body condition index was calculated as a measure of thickness based on M. l. lebetina body weight and length $[21,22]$. As published data on sex-specific morphological differences in M. lebetina are scarce and sometimes contradictory, comparing different morphological characteristics between male and female blunt-nosed vipers can contribute to filling this knowledge gap. Based on the literature [8, 17], we formulated and tested three hypotheses: (1) On average, adult males are larger in snout-vent length (SVL) than adult females. (2) The ratio of tail length to snout-vent length (TaL / SVL) is smaller in adult males than in adult females. (3) In late summer (after the mating season), adult females are thinner than in spring (during the mating season).

Reptiles in semi-arid regions are often confronted with annual droughts. The resulting periodic water scarcity affects their spatial distribution, foraging ecology and body condition. Water availability is an important factor for survival as it may also determine the presence or absence of prey species and shelter from overheating and natural enemies [23, 24]. As water bodies are critical for sustaining both wildlife and human civilization, they have been facilitating contact between people and reptiles for millennia. In some areas, this contact has contributed to the problematic relationship between humans and venomous snakes. During the summer months, when many natural water bodies dry out in Cyprus, $M$. l. lebetina is frequently observed close to water [17, 25] and can even be found in swimming pools. Bites have occurred at waterholes [17]. Although a better understanding of $M$. l. lebetina distribution patterns and habitat requirements can contribute to minimizing human-viper conflicts, little is known about the importance of water for the spatial ecology of this species. In this study we therefore also investigated the relationship between water occurrence and blunt-nosed viper presence in Cyprus, via analysis of distances of the vipers to the nearest body of artificial and (or) natural freshwater body.

\section{Methods \\ Data collection}

Data collection took place during three field surveys in northern Paphos district, Cyprus (ca. 3502' N, 32 $26^{\prime}$ E), from 24 March to 4 June 2014, 27 August to 29 September 2015 and 21 September to 3 October 2017. This coastal lowland area is characterized by agriculture in the Polis Chrysochous valley, bordering Akamas Peninsula in the west and the forested foothills of the Troodos Mountains in the east (Fig. 1, see [26, 27]). Daily mean temperatures range from $12.1{ }^{\circ} \mathrm{C}$ in January to $27.6^{\circ} \mathrm{C}$ in July and August, with maximum temperatures of $\geq 40{ }^{\circ} \mathrm{C}$ during summer. Mean annual precipitation is $394.2 \mathrm{~mm}$, of which $380.9 \mathrm{~mm}$ falls between October and April, and $13.3 \mathrm{~mm}$ between May and September [28]. Potential viper habitats in Polis municipality and surroundings were systematically examined via a transect survey [29]. Sixteen transects were placed across different potential viper habitats classified as (1) edges along streambanks and water pools, (2) edges along grain fields, orchards and pastures, (3) agrarian landscape mosaic with ruins of a deserted village, (4) shrubby slopes (maquis and garrigue habitat) in eastern Akamas Peninsula. Over each habitat, $1500 \mathrm{~m}$ of transect line was spread, divided into three 500-m-long sections. Additionally, field trips were made to nearby gorges (Androlikou, Petratis and Avakas) and dammed reservoirs (Evretou, Argaka, Agia Marina and Kannaviou), as well as to western Akamas Peninsula and the Troodos Mountains. Road-cruising was applied as a further survey method. Diurnal transect surveys amounted to 8 hours $\mathrm{h}$ daily throughout spring (starting at 8:00 AM), and 


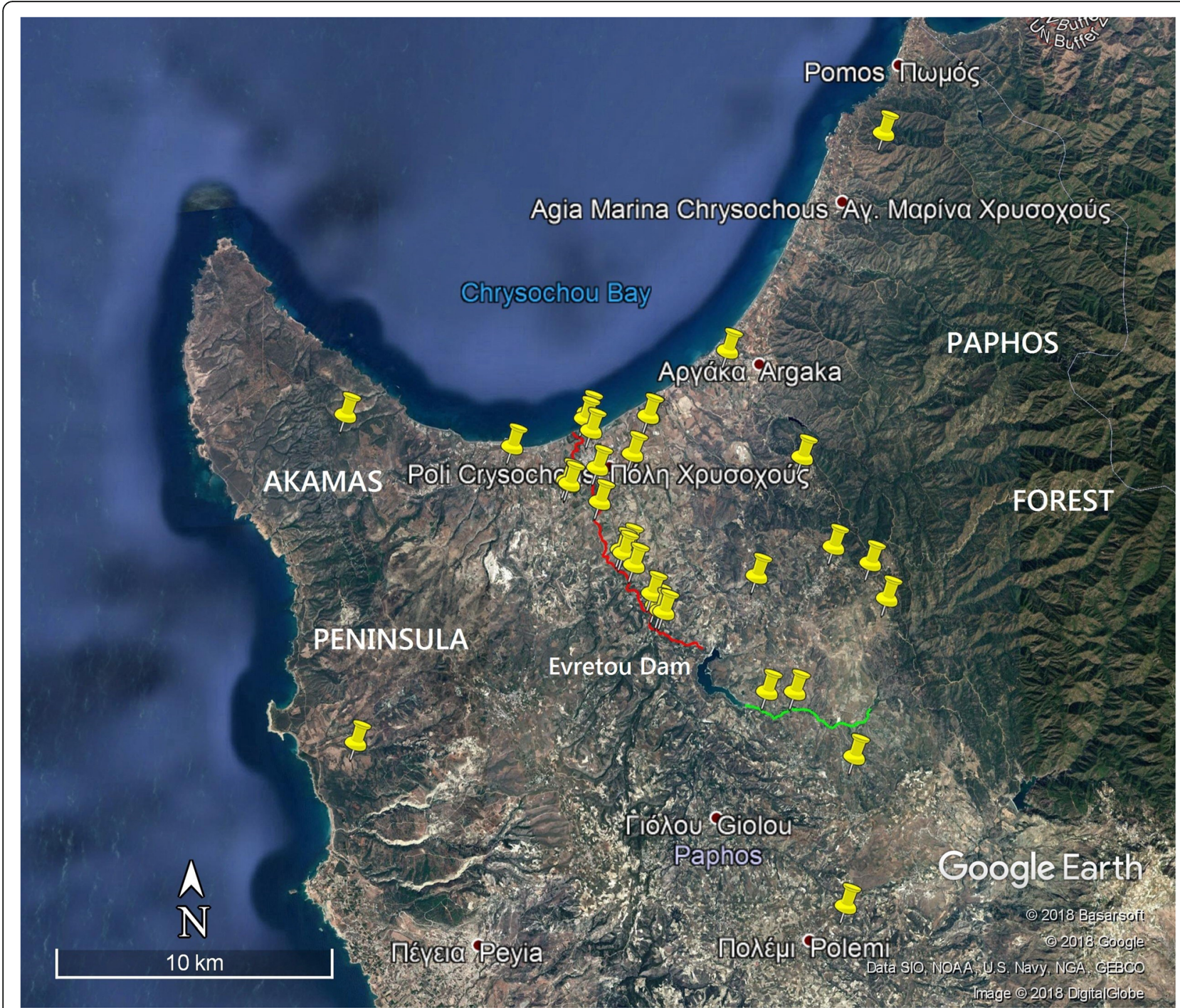

Fig. 1 The study area in northern Paphos district: Polis Chrysochous municipality ( $\left.35^{\circ} 02^{\prime} \mathrm{N}, 32^{\circ} 26^{\prime} \mathrm{E}\right)$ and surroundings, bordered by Akamas Peninsula in the west and Paphos Forest (Troodos Mountains) in the east. The Chrysochous River is highlighted in red. The lower section of the Stavros tis Psokas River, which flows into the Evretou Reservoir, is highlighted in green. The yellow pin markers represent the locations of the recorded M. I. lebetina specimens from this study, with one individual from near Kakopetria (Nicosia district) not included

nocturnal surveys to $4 \mathrm{~h}$ daily in late summer (starting at 20:00 PM). During late summer, daily diurnal survey time was reduced to $4 \mathrm{~h}$ in the morning and early evening time. Three to four days were needed to examine all 16 transects (including field data collection), before repeating the process. Transect lines were walked in both directions and carefully checked for blunt-nosed vipers within a range of $20 \mathrm{~m}$. At every viper observation point, the date, time, climatic and GPS data were collected and the shortest distance to the nearest water body was measured. Distances were measured with a $30 \mathrm{~m}$ tape in the field or otherwise on the computer with the Google Maps distance calculator. Swimming pools and other man-made reservoirs supplied by piped water were defined as artificial water bodies, whereas streams, natural springs, reservoirs and lakes were considered natural water bodies. Live individuals of $M$. l. lebetina were caught for the collection of biometric data. Body weight was measured to the nearest gram (mean of five measurements) using a Beurer digital scale. Snout-vent length, tail length (TaL) and ToL were measured to the nearest $0.5 \mathrm{~cm}$ in live individuals and to the nearest 1 $\mathrm{mm}$ in dead ones. For statistical purposes, SVL, TaL and ToL of dead specimens were later rounded to the nearest $0.5 \mathrm{~cm}$. Head length (HL) and head width (HW) were measured to the nearest $1 \mathrm{~mm}$. Ventral, subcaudal and dorsal scales were counted, the latter at mid-body. The sex was determined via examination of the tail base and cloaca in live specimens, and via probing of the hemipenes in dead individuals [17]. Vipers below $70 \mathrm{~cm} \mathrm{ToL}$ 
were considered sub-adult [11]. To avoid ambiguity in sex determination and risk of injury, juveniles were not sexed. Following Benson (1999), a digital photograph of the anal plate of each specimen was taken for individual recognition [30]. After being kept in captivity for up to $24 \mathrm{~h}$, live individuals were relocated to their native areas, or, if captured in residential areas, to the nearest appropriate habitat. Four specimens (SNM-BS N-56085 to $\mathrm{N}-56088$ ) found dead in good condition were collected and stored in $90 \%$ ethanol. They were later transferred to Braunschweig State Natural History Museum (Germany) and dissected for a stomach content analysis. In addition to these morphological and ecological data, semistructured interviews on human interaction with $M$. $l$. lebetina were conducted with staff of Cypriot institutions and local people related to environmental management, outdoor labor and medicine.

\section{Statistical analysis}

For all collected morphometric measurements, the mean, standard deviation (SD) and coefficient of variation (CV) were calculated. As a body condition index (BCI) for each snake, Fulton's index (K) was calculated using the formula $K=\frac{W e i g h t}{S V L^{3}} \times 10^{5}[21,22]$. Prior to statistical analysis, all distance and morphometric data were tested for normality using the Shapiro-Wilk test. Due to non-normality of the distribution, the Mann-Whitney $U$ test was applied to compare the nearest distances to water in the spring of 2014 with those taken in late summer of 2015. For the comparison of the nearest distances to artificial and natural water bodies in the spring of 2014 (late summer of 2015), the Wilcoxon matched pairs test was applied. Relationships between morphometric characteristics were examined via regression and correlation analysis. We assumed that the relationship between SVL and weight (W) could be described by the exponential regression equation $W=a S V L^{b}$, where $a$ and $b$ are constant [31]. The coefficients $a$ and $b$ were estimated for the linearized form of the equation (after log-transformation of both sides of the equation) $\log W=\log a+b S V L$, using the least squares method. The coefficient of determination $\left(R^{2}\right)$ was used as a measure of the fraction of weight variation that can be explained by SVL. The correlation coefficient $\mathrm{R}$ was used as a measure of the strength of the linear relationship between SVL and TaL, SVL and HL, SVL and HW, and between HL and HW. Morphometric properties and the $\mathrm{BCI}$ of adult males and females were compared using the unpaired $t$ test for normally distributed variables or the Mann-Whitney $U$ test for non-normally distributed variables. For all tests, results were considered to be significant when $P<0.05$. All statistical analyses were performed using the software Statistica 13.2 (StatSoft, Inc., USA).

\section{Results}

\section{Habitat}

Macrovipera l. lebetina was observed at edges of agricultural plantations, grain fields, gardens and streambanks, on grassy slopes, and inside dried-out streambeds. Besides shrubs and thick grassy vegetation, habitats with confirmed blunt-nosed viper presence contained a variety of microstructures such as crevices and caves, animal dens, stone slabs, rock piles, rock walls, and ruins of buildings and other constructions. Ten blunt-nosed vipers were recorded in private gardens (April 2014, July and September 2015), two in a building next to a swimming pool (3 and 19 May 2014) and a killed (newborn) viper at a building entrance door (21 September 2015). An adult female was found inside a pickup truck into which it had crawled when the vehicle had briefly stopped on a dirt road (23 September 2015). Common plant species of surveyed M. l. lebetina habitats in Paphos district included oriental alder (Alnus orientalis), giant reed (Arundo donax), common fig tree (Ficus carica), Phoenician juniper (Juniperus phoenicea), olive tree (Olea europaea), lentisk (Pistacia lentiscus), oriental plane (Platanus orientalis), holy bramble (Rubus ulmifolius sanctus) and the exotic eucalypt (Eucalyptus spp.).

\section{Food habits}

The stomach of an adult female blunt-nosed viper (SVL $109.0 \mathrm{~cm}$, TaL $14.8 \mathrm{~cm}$, weight 1225 g; SNM-BS N-56086) contained remains of a tawny pipit (Anthus campestris). This snake was found killed on a country road (10 April 2014). A live adult female (SVL $86.5 \mathrm{~cm}, \mathrm{TaL} 11.5 \mathrm{~cm}$ ) caught on 1 May 2014 (11:07 AM) at the edge of a stream bank next to an olive tree plantation regurgitated a half-digested, adult brown rat (Rattus norvegicus) of $270 \mathrm{~g}$ after $5 \mathrm{~h}$ in captivity (Fig. 2f). After regurgitation, the body weight of the snake had dropped from 1123 to $835 \mathrm{~g}$. The skull of a broad-toothed field mouse (Apodemus mystacinus) was found in the stomach of a killed adult male viper (SVL $92.3 \mathrm{~cm}$, TaL $13.2 \mathrm{~cm}$, weight $730 \mathrm{~g}$; SNM-BS $\mathrm{N}-56087)$ lying on a small village road (12 May 2014). A killed male found on 17 September 2015 (SVL $117.3 \mathrm{~cm}$, TaL $14.5 \mathrm{~cm}$, weight $1302 \mathrm{~g}$ ) contained remains from a rodent, most likely a brown rat.

\section{Shedding locations}

Two blunt-nosed viper shedding localities were recorded during the field survey. On 1 April 2014, the slough of a large adult viper (about $1.2 \mathrm{~m} \mathrm{ToL}$ ) was found at the edge of an orange tree plantation and grazing pastures interspersed with almond trees. The slough was in the grass next to a pile of wooden debris. Two adult females $(\mathrm{SVL}=65.5$ and $93.0 \mathrm{~cm})$ were later observed $33 \mathrm{~m}(6$ May 2014) and $119 \mathrm{~m}$ (2 September 2015) away, respectively. The distance of the slough to the next water body 

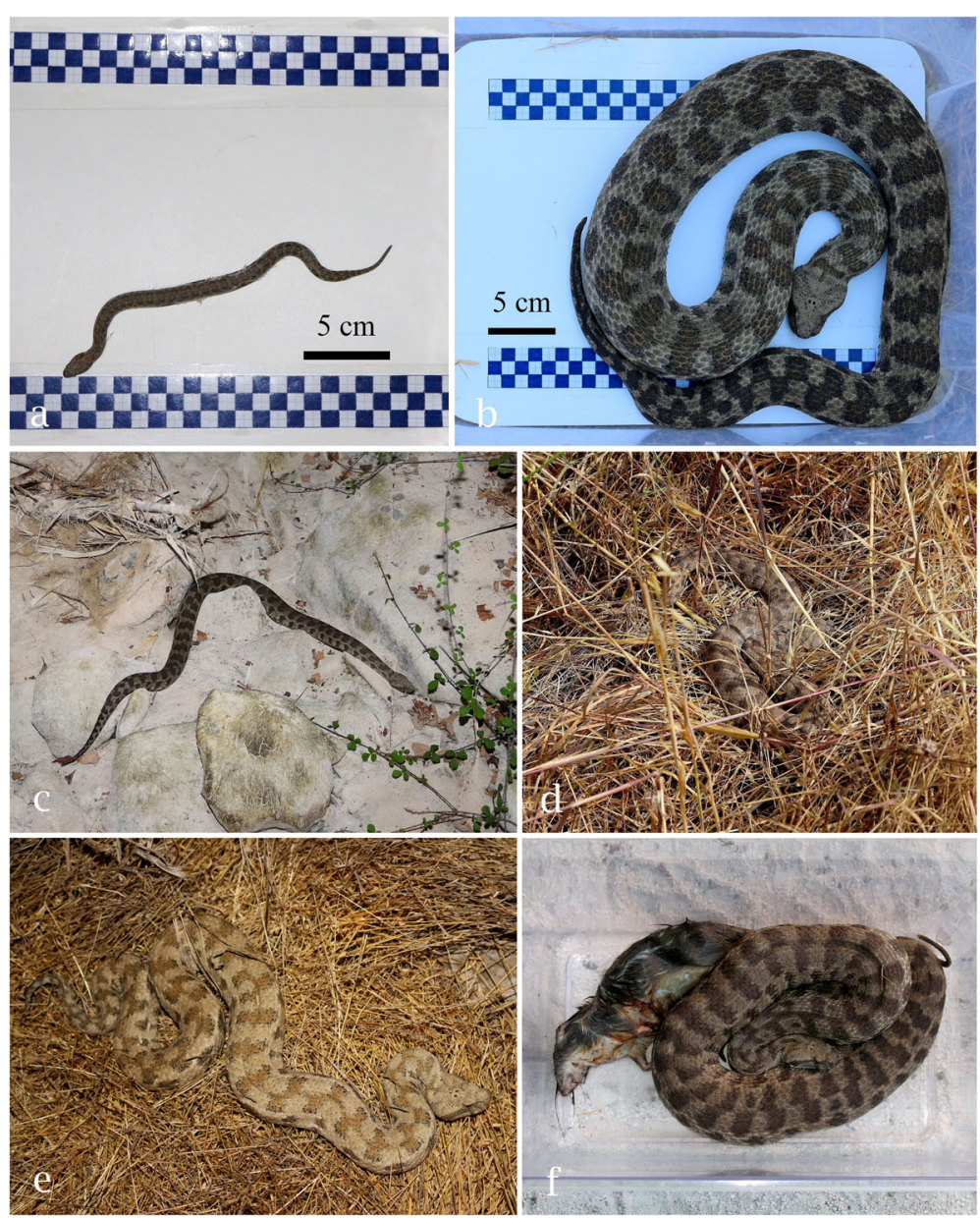

Fig. 2 a Dorsal view of a neonate blunt-nosed viper (SVL: $20.5 \mathrm{~cm}$, TaL: $3 \mathrm{~cm}$, weight: $10 \mathrm{~g}$ ) with a $5 \mathrm{~cm}$ scale (11 September 2015). The skin is partially shed. b Dorsal view of an adult male blunt-nosed viper (SVL: $116.5 \mathrm{~cm}$, TaL: $14.5 \mathrm{~cm}$, weight: $1441 \mathrm{~g}$ ) with a $5 \mathrm{~cm}$ scale. c The individual from $2 \mathrm{~b}$ in a periodically dry streambed where it was found in ambush position on 6 September 2015, 22:05 PM. d Young adult female blunt-nosed viper (SVL: 65.5 cm, TaL: $9 \mathrm{~cm}$, weight: $279 \mathrm{~g}$ ) basking well-camouflaged at the edge of cropland after rainfall (6 May 2014, 15:45 PM). e Adult male blunt-nosed viper from Akamas Peninsula (SVL: $92.5 \mathrm{~cm}$, TaL: $12.5 \mathrm{~cm}$, weight: $749 \mathrm{~g}$ ), found in maquis and garrigue shrubland (28 September 2017, 20:45 PM). f Adult female blunt-nosed viper (SVL: $86.5 \mathrm{~cm}$, TaL: $11.5 \mathrm{~cm}$, weight: $835 \mathrm{~g}$ ) with a regurgitated brown rat (Rattus norvegicus) of $270 \mathrm{~g}$. Found moving along a stream bank (Fig. 3a). Photos: D. Jestrzemski

(an artificial, permanent reservoir) was $137 \mathrm{~m}$. The slough remnant of another large adult blunt-nosed viper (including a $15.5 \mathrm{~cm}$ long tail section) was discovered inside a periodically dry streambed with several small water pools on 27 September 2015. In the same month (6 and 29 September), two large vipers were recorded $76 \mathrm{~m}$ and $67 \mathrm{~m}$ upstream from this shedding location. The individual of 6 September was an adult male (SVL $=116.5 \mathrm{~cm}, \mathrm{TaL}=14.5 \mathrm{~cm}$ ).

\section{Bite accidents by Macrovipera lebetina in Cyprus}

During the field study, news was received of at least four incidences of human envenoming following snakebite in the study area. In one case (on 15 September 2015), a woman was bitten on her foot by a juvenile blunt-nosed viper next to her swimming pool (S. Paphitis pers. comm. 17 September 2015). As a survey of snakebite epidemiology was beyond the scope of the present study, it is possible that additional people in the area might have been bitten by vipers during the study period. Livestock and hunting dogs are bitten by $M$. l. lebetina every year (H.-J. Wiedl pers. comm. 29 March 2014; K. Kailis pers. comm. 15 April 2014; H. Demetriades pers. comm. 29 May 2014). In summer, bite accidents happen especially when goats and sheep concentrate around waterholes frequented by vipers (H. Hadjistyllis pers. comm. 6 June 2014; Fig. 3b).

\section{Conservation status}

During the 2014 survey (between 3 April and 26 May), 13 blunt-nosed vipers were found killed on roads in Paphos district (Polis area) with injuries including smashed 


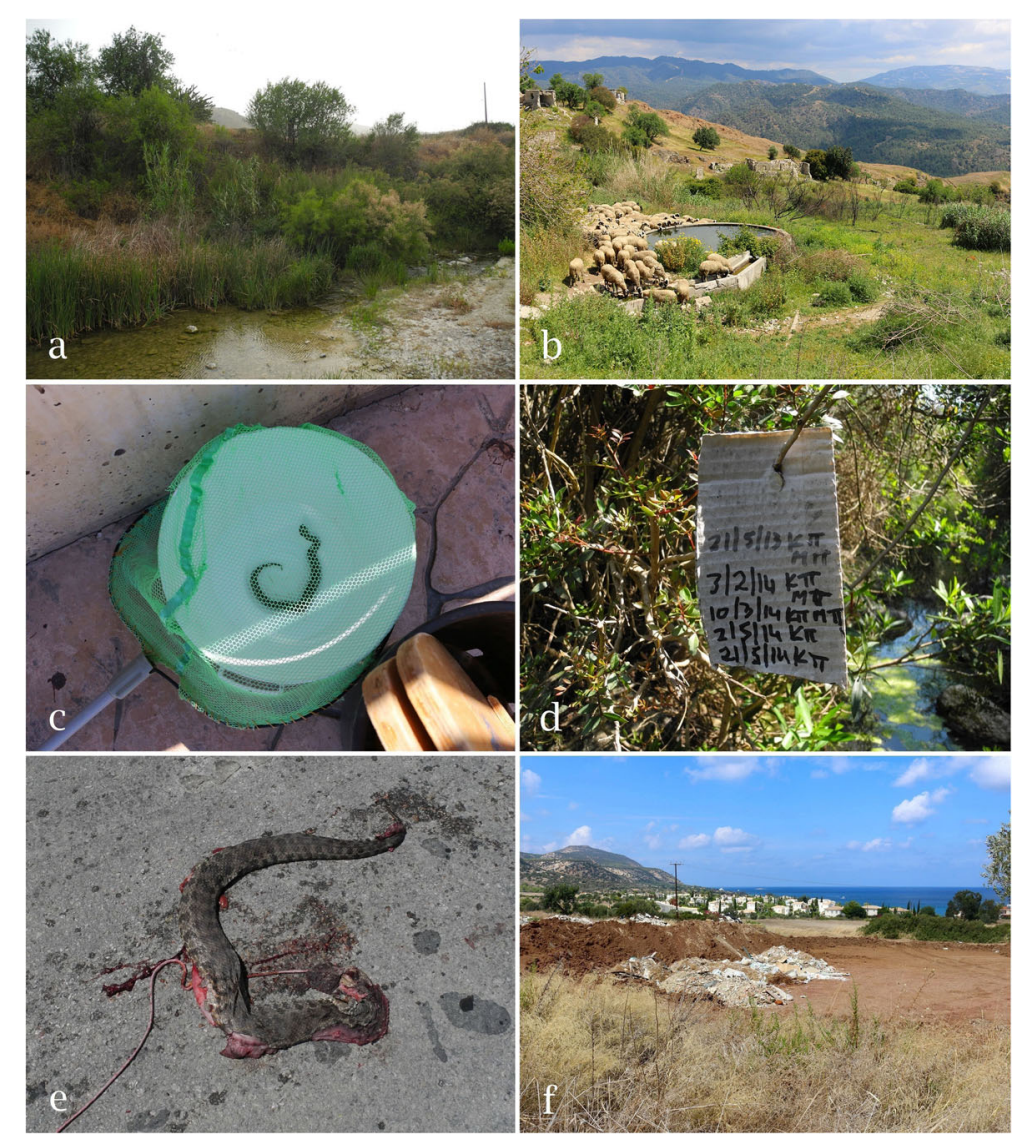

Fig. 3 a Richly structured stream bank with adjacent agricultural areas: habitat of the blunt-nosed viper. b Rocky slopes with shrubs and ruins: blunt-nosed viper habitat used for sheep and goat grazing. c Juvenile blunt-nosed viper caught by children at noon (12:40 PM) in a residential swimming pool in central Paphos district (13 September 2015). e Signatures of mosquito control workers at a stream show that this riparian area - habitat of M. I. lebetina - is regularly visited by people. e Blunt-nosed viper killed and dragged on the road with a string attached to the snake's neck (14 April 2014). f Destruction of wild blunt-nosed viper habitat for real-estate development on Akamas Peninsula (1 October 2017). Loss of pristine habitats is a common problem in coastal areas of Cyprus. Photos: D. Jestrzemski

heads, necks and cloacae. In two cases, a string was attached to the body of the snake (Fig. 3e). On 17 September 2015, a large dead male was found underneath the edge of a road bridge in a dried-out streambed, with its skull smashed and its stomach content protruding from its open gut. Interviews confirmed that $M$. l. lebetina is feared and persecuted by local people both in populated areas and in the wild. Road traffic is another threat. People involved in outdoor activities (farmers, forestry employees, game wardens, hunters, mosquito control workers and shepherds) encounter vipers more often in comparison with other occupational groups. The widespread public aversion to $M$. l. lebetina has so far prevented legal protection of this species in Cyprus ([17]; E. Erotokritou, H. Nicolaou pers. comm. 28 May 2014). Additionally, wild viper habitat is continuously destroyed by real-estate development, an ongoing trend in coastal areas (pers. obs., Figure 3f). Man-made wildfires occur every year. In June 2016, 751 hectares of vegetation were burned down in the Argaka area (H. Nicolaou pers. comm. 17 March 2018).

\section{Morphometric measurements}

Morphometric data (Table 1) were collected on 34 vipers (10 adult males, 16 adult females and eight unsexed juveniles). Of these, 29 were alive and five (three males and two females) dead. No individuals were recaptured. Blunt-nosed viper rounded total lengths and weights ( $n$ =34) ranged from $23.5 \mathrm{~cm}(10 \mathrm{~g})$ for juveniles to 133.0 cm (1456 g) for a killed adult male (SNM-BS N-56085). The three largest males exceeded $130 \mathrm{~cm}$ ToL whereas the largest female (SNM-BS N-56086) had a rounded ToL of $124.0 \mathrm{~cm}$. Rounded SVL ranged from $20.5 \mathrm{~cm}$ to $119.5 \mathrm{~cm}$ (Fig. 4). While the two heaviest males exceeded $1400 \mathrm{~g}$ body weight, the heaviest female, a gravid individual, weighed $1228 \mathrm{~g}$ (Fig. 5). The lowest (66) and highest (146) Fulton's body condition index (K) was observed in adult females, whereas the range of $K$ was much 
Table 1 Morphometric characteristics of juvenile and adult blunt-nosed vipers from Cyprus (SVL, TaL and ToL rounded to the nearest $0.5 \mathrm{~cm}$ )

\begin{tabular}{|c|c|c|c|c|c|}
\hline Sex/Re-productive condition & Measurement & $\mathrm{n}$ & Range & Mean \pm SD & Coefficient of Variation (\%) \\
\hline \multirow[t]{11}{*}{ All } & $\mathrm{SVL}(\mathrm{cm})$ & 34 & $20.5-119.5$ & $76.54 \pm 28.30$ & 36.97 \\
\hline & TaL (cm) & 34 & $3.0-15.0$ & $9.76 \pm 3.51$ & 35.93 \\
\hline & ToL (cm) & 34 & $23.5-133.0$ & $86.32 \pm 31.49$ & 36.47 \\
\hline & $\mathrm{HL}(\mathrm{mm})$ & 32 & $16-54$ & $40.59 \pm 10.89$ & 26.82 \\
\hline & $\mathrm{HW}(\mathrm{mm})$ & 32 & $10-44$ & $30.47 \pm 9.21$ & 30.24 \\
\hline & Weight (g) & 34 & $10-1456$ & $584.65 \pm 432.05$ & 73.90 \\
\hline & TaL / SVL & 34 & $0.07-0.16$ & $0.13 \pm 0.02$ & 15.65 \\
\hline & TaL / ToL & 34 & $0.06-0.14$ & $0.12 \pm 0.02$ & 14.28 \\
\hline & $\mathrm{HL} / \mathrm{SVL}$ & 32 & $0.04-0.10$ & $0.06 \pm 0.01$ & 22.76 \\
\hline & $\mathrm{HL} / \mathrm{HW}$ & 32 & $1.18-1.70$ & $1.36 \pm 0.12$ & 8.51 \\
\hline & $\mathrm{BCl}(\mathrm{K})$ & 34 & $66-146$ & $101.06 \pm 18.41$ & 18.21 \\
\hline \multirow[t]{11}{*}{ Adult males } & SVL (cm) & 10 & $71.0-119.5$ & $96.75 \pm 18.93$ & 19.57 \\
\hline & TaL (cm) & 10 & $10.0-14.5$ & $12.80 \pm 1.40$ & 10.93 \\
\hline & ToL (cm) & 10 & $81.0-133.0$ & $109.60 \pm 20.24$ & 18.47 \\
\hline & $\mathrm{HL}(\mathrm{mm})$ & 10 & $40-54$ & $48.60 \pm 5.52$ & 11.36 \\
\hline & $\mathrm{HW}$ (mm) & 10 & $31-44$ & $36.70 \pm 4.67$ & 12.72 \\
\hline & Weight (g) & 10 & $346-1456$ & $894.20 \pm 420.79$ & 47.06 \\
\hline & TaL / SVL & 10 & $0.11-0.16$ & $0.13 \pm 0.02$ & 11.17 \\
\hline & TaL / ToL & 10 & $0.10-0.14$ & $0.12 \pm 0.01$ & 9.92 \\
\hline & $\mathrm{HL} / \mathrm{SVL}$ & 10 & $0.05-0.06$ & $0.05 \pm 0.00$ & 9.25 \\
\hline & $\mathrm{HL} / \mathrm{HW}$ & 10 & $1.23-1.42$ & $1.33 \pm 0.06$ & 4.48 \\
\hline & $\mathrm{BCl}(\mathrm{K})$ & 10 & 80-114 & $93.40 \pm 9.99$ & 10.70 \\
\hline \multirow[t]{11}{*}{ Adult females } & $\mathrm{SVL}(\mathrm{cm})$ & 16 & $65.5-109.0$ & $84.66 \pm 12.47$ & 14.73 \\
\hline & TaL (cm) & 16 & $5.5-15.0$ & $10.22 \pm 2.30$ & 22.53 \\
\hline & ToL (cm) & 16 & $74.5-124.0$ & $94.88 \pm 13.74$ & 14.48 \\
\hline & $\mathrm{HL}(\mathrm{mm})$ & 14 & $36-48$ & $43.71 \pm 3.67$ & 8.39 \\
\hline & $\mathrm{HW}(\mathrm{mm})$ & 14 & $28-40$ & $33.64 \pm 3.69$ & 10.97 \\
\hline & Weight (g) & 16 & $279-1228$ & $649.88 \pm 300.90$ & 46.30 \\
\hline & TaL / SVL & 16 & $0.07-0.15$ & $0.12 \pm 0.02$ & 19.20 \\
\hline & TaL / ToL & 16 & $0.06-0.13$ & $0.11 \pm 0.02$ & 17.65 \\
\hline & $\mathrm{HL} / \mathrm{SVL}$ & 14 & $0.04-0.06$ & $0.05 \pm 0.00$ & 7.04 \\
\hline & $\mathrm{HL} / \mathrm{HW}$ & 14 & $1.18-1.47$ & $1.30 \pm 0.08$ & 6.01 \\
\hline & $\mathrm{BCl}(\mathrm{K})$ & 16 & $66-146$ & $103.00 \pm 22.43$ & 21.77 \\
\hline \multirow[t]{10}{*}{ Juveniles } & $\mathrm{SVL}(\mathrm{cm})$ & 8 & $20.5-59.5$ & $35.06 \pm 16.74$ & 47.75 \\
\hline & TaL (cm) & 8 & $3.0-8.5$ & $5.06 \pm 2.29$ & 45.24 \\
\hline & ToL (cm) & 8 & $23.5-68.0$ & $40.13 \pm 19.03$ & 47.42 \\
\hline & $\mathrm{HL}(\mathrm{mm})$ & 8 & $16-34$ & $25.13 \pm 8.72$ & 34.73 \\
\hline & $\mathrm{HW}(\mathrm{mm})$ & 8 & $10-24$ & $17.13 \pm 6.60$ & 38.54 \\
\hline & Weight (g) & 8 & $10-218$ & $67.25 \pm 76.04$ & 113.06 \\
\hline & TaL / SVL & 8 & $0.13-0.16$ & $0.15 \pm 0.01$ & 4.58 \\
\hline & TaL / ToL & 8 & $0.12-0.14$ & $0.13 \pm 0.01$ & 3.99 \\
\hline & $\mathrm{HL} / \mathrm{SVL}$ & 8 & $0.06-0.10$ & $0.08 \pm 0.01$ & 18.69 \\
\hline & $\mathrm{HL} / \mathrm{HW}$ & 8 & $1.33-1.70$ & $1.49 \pm 0.12$ & 8.33 \\
\hline
\end{tabular}


Table 1 Morphometric characteristics of juvenile and adult blunt-nosed vipers from Cyprus (SVL, TaL and ToL rounded to the nearest $0.5 \mathrm{~cm}$ ) (Continued)

\begin{tabular}{|c|c|c|c|c|c|}
\hline Sex/Re-productive condition & Measurement & $n$ & Range & Mean \pm SD & Coefficient of Variation (\%) \\
\hline & $\mathrm{BCl}(\mathrm{K})$ & 8 & $80-125$ & $106.75 \pm 16.18$ & 15.15 \\
\hline \multirow[t]{11}{*}{ Adults } & $\mathrm{SVL}(\mathrm{cm})$ & 26 & $65.5-119.5$ & $89.31 \pm 16.07$ & 18.00 \\
\hline & TaL (cm) & 26 & $5.5-15.0$ & $11.21 \pm 2.35$ & 20.96 \\
\hline & ToL (cm) & 26 & $74.5-133.0$ & $100.54 \pm 17.73$ & 17.63 \\
\hline & $\mathrm{HL}(\mathrm{mm})$ & 24 & $36-54$ & $45.75 \pm 5.06$ & 11.06 \\
\hline & $\mathrm{HW}(\mathrm{mm})$ & 24 & $28-44$ & $34.92 \pm 4.31$ & 12.35 \\
\hline & Weight (g) & 26 & $279-1456$ & $743.85 \pm 364.37$ & 48.98 \\
\hline & TaL / SVL & 26 & $0.07-0.16$ & $0.13 \pm 0.02$ & 16.77 \\
\hline & TaL / ToL & 26 & $0.06-0.14$ & $0.11 \pm 0.02$ & 15.33 \\
\hline & $\mathrm{HL} / \mathrm{SVL}$ & 24 & $0.04-0.06$ & $0.05 \pm 0.00$ & 7.90 \\
\hline & $\mathrm{HL} / \mathrm{HW}$ & 24 & $1.18-1.47$ & $1.31 \pm 0.07$ & 5.37 \\
\hline & $\mathrm{BCl}(\mathrm{K})$ & 26 & $66-146$ & $99.31 \pm 18.98$ & 19.12 \\
\hline
\end{tabular}

narrower among adult males (80-114) and juveniles (80-125). The mean ratio of TaL to ToL was $11.85 \pm$ $1.18 \%$ for adult males $(n=10)$ and $10.80 \pm 1.91 \%$ for adult females $(n=16)$. The coefficient of variation was highest for the variable weight, ranging from $46 \%$ in adult females to $113 \%$ in juveniles.

Figure 6 represents the relationship between natural logarithms of weight and natural logarithms of SVL for all examined vipers by a fitted regression line. The coefficient of determination $\mathrm{R}^{2}$ amounted to 0.99 . In comparison, Fig. 7 demonstrates a relationship between original data with a fitted exponential function whose coefficients were estimated based on the linear regression approach. In adult females, the relationship between weight and SVL was much weaker $\left(R^{2}=0.73\right)$ than in juveniles and adult males $\left(R^{2}=0.97\right.$ and $R^{2}=0.99$ respectively) (Table 2). Adult females also showed the weakest relationship between SVL and TaL, SVL and HL, SVL and HW, and between HL and HW (Table 3). The correlation between all characteristics was significant at the 0.05 level.

Morphometric characteristics SVL vs. TaL, SVL vs. HL, SVL vs. HW, and HL vs. HW of juveniles, adult males and adult females. For TaL, only undamaged tails were considered. All correlation coefficients were significant at the 0.05 level.

According to the $t$ test, SVL, HW and weight were not significantly different between adult males and females at the 0.05 level, although $P$ was relatively low: $P$ values were calculated as $0.060,0.087$ and

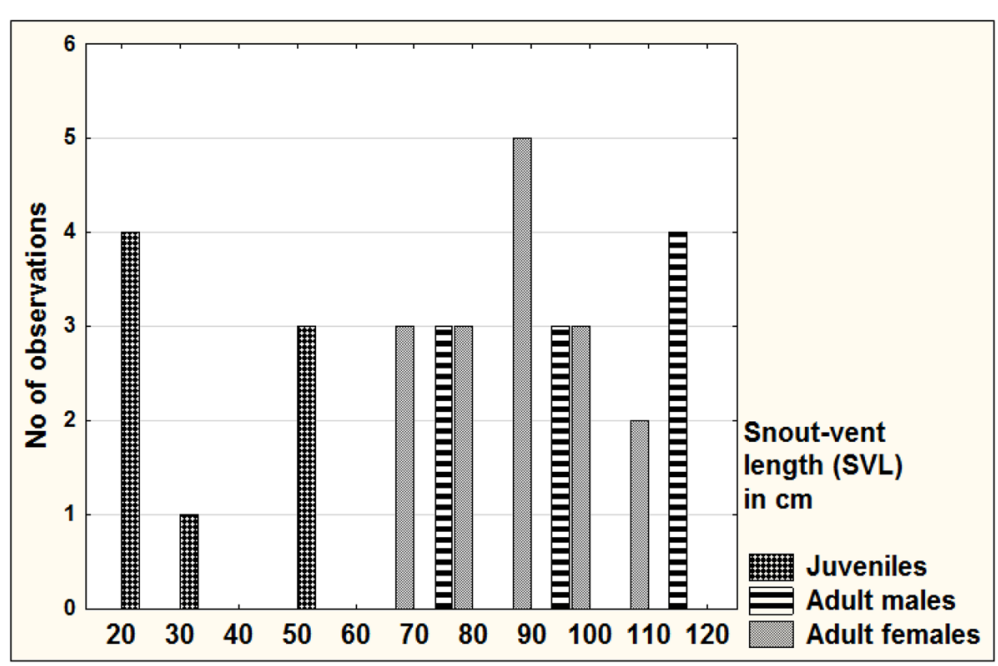

Fig. 4 Distribution of SVL among 34 blunt-nosed vipers from Cyprus 


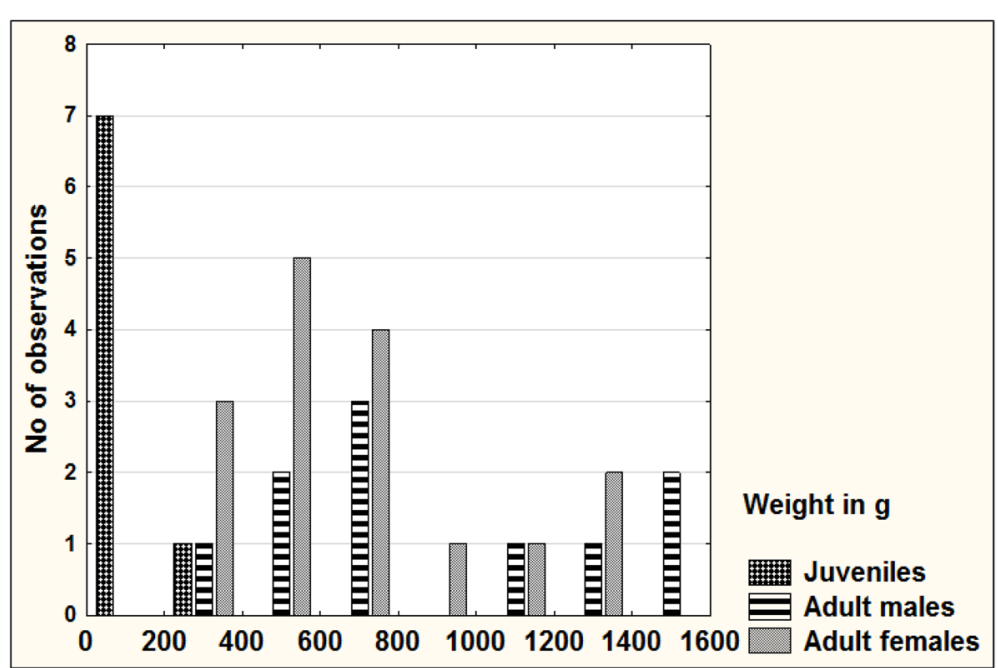

Fig. 5 Distribution of weight among 34 blunt-nosed vipers from Cyprus

0.097 for average SVL, HW and weight, respectively. Adult males were significantly longer in average TaL $(P=0.005)$, average ToL $(P=0.047)$ and average $\mathrm{HL}$ $(P=0.016)$. No significant sex-specific differences were found for HL / SVL, HL / HW and BCI (Table 4). The Mann-Whitney U test (Table 5) did not show a significant sex-specific difference for the ratios of TaL / SVL $(P=0.285)$ and TaL/ToL $(P=0.285)$. These results indicate that adult females did not have longer tails than adult males relative to their body length.

Adult females observed in the late summer of $2015(n=5)$ had a significantly lower mean BCI than those found in the spring of 2014 $(n=11)(P=$ 0.0007). Among adult males, the mean BCI was significantly lower in the four longest individuals (SVL $\geq 100$ $\mathrm{cm})$ than in the six smaller ones $(\mathrm{SVL}<100 \mathrm{~cm})(P=$ 0.013).

For measurements involving TaL, only individuals with undamaged tails were considered.

\section{Distance to water}

Of 38 total field observations, 36 blunt-nosed vipers were recorded with corresponding distances to the nearest body of artificial and (or) natural freshwater in $2014(n=19)$

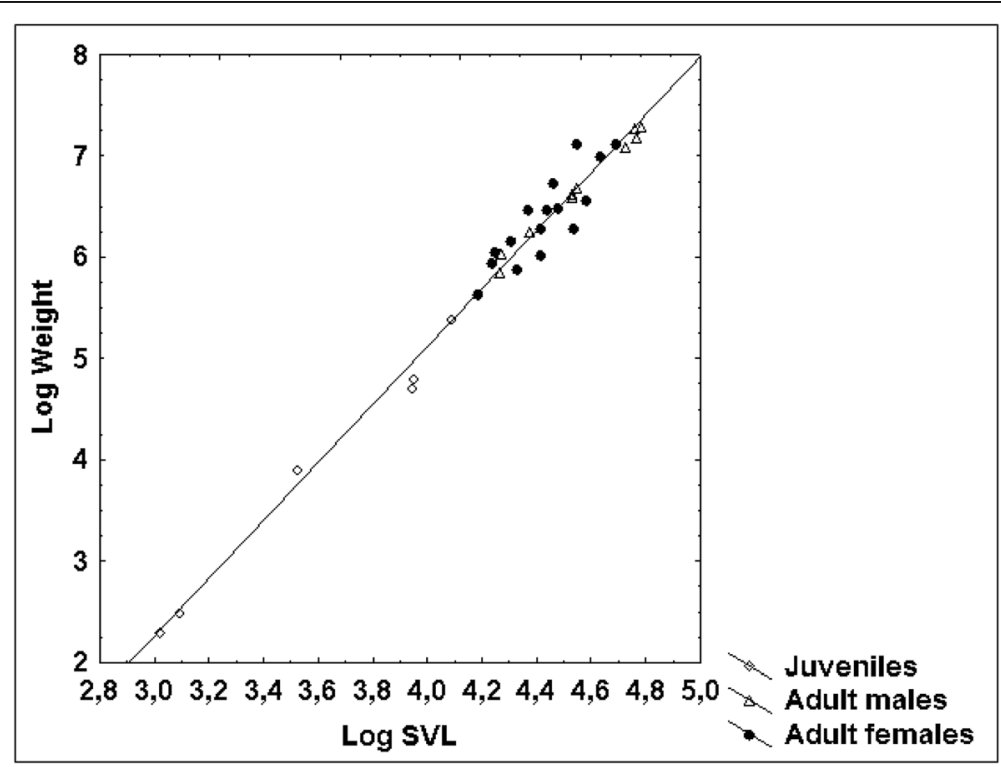

Fig. 6 Relationship between log-transformed SVL and log-transformed weight in 34 blunt-nosed vipers from Cyprus: $Y=-6.32+2.86^{*} X . R^{2}=0.99$ 


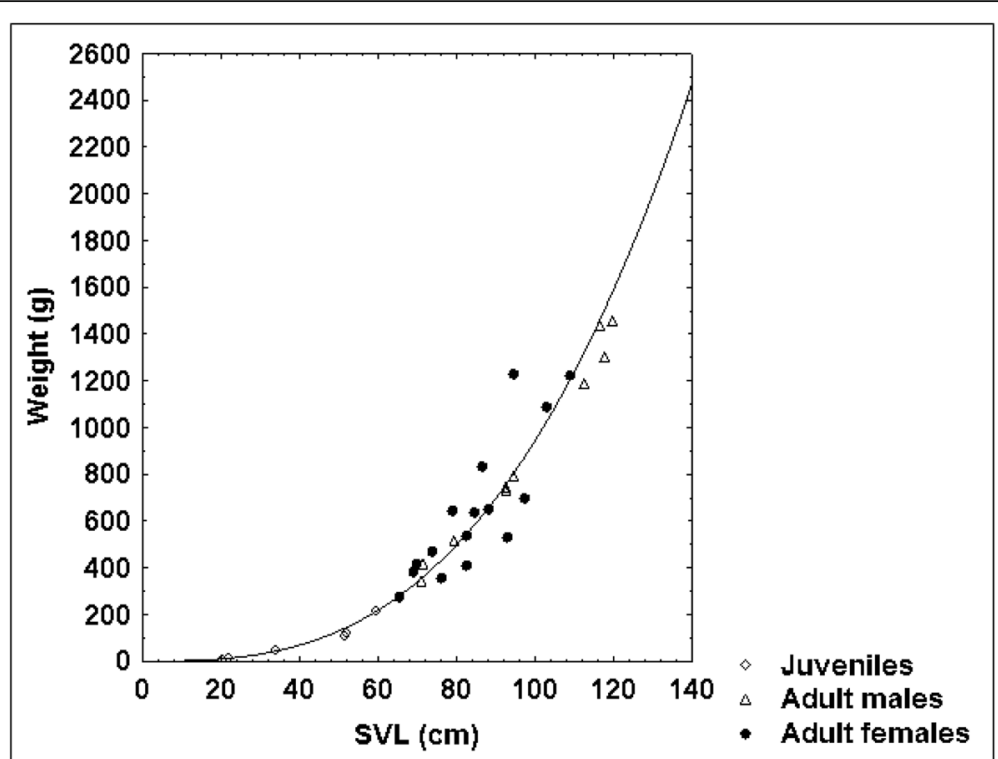

Fig. 7 Allometric relationship between SVL and weight in 34 blunt-nosed vipers from Cyprus: $Y=\exp .(-6.32)^{*} X^{286}$

and in $2015(n=17)$ (Table 6). For a single observation in 2015 , only the nearest distance to artificial water was recorded, decreasing the number of viper observations with both the nearest distance to artificial and to natural water bodies available by the value of $1(2015: n=16)$. Out of the 36 observed vipers, 24 individuals could be captured for data collection whereas 11 vipers either escaped or were killed by local people. In one case, a viper slough was treated as a single individual. At the site where a large male was observed, another large viper was recorded 21 days later, as were remains of a slough belonging to a similarly sized individual. To exclude the possibility of double-counting, all three observations were treated as one individual. Assumption of normality was rejected for all distances of M. l. lebetina to the nearest water bodies. The Mann-Whitney U test showed no significant difference between the distances of $M$. l. lebetina to the nearest water bodies in the spring of 2014 and late summer of $2015(P=0.537)$. Likewise, the distances of $M$. l. lebetina to natural water bodies in the spring of 2014 did not vary

Table 2 Sample sizes, parameter and coefficient of determination $\left(R^{2}\right)$ of the regression: $\log W=\log a+b \cdot \log S V L$ of blunt-nosed vipers from Cyprus

\begin{tabular}{lllll}
\hline & $\mathrm{N}$ & $\mathrm{R}^{2}$ & $\mathrm{a}$ & $\mathrm{b}$ \\
\hline SVL vs. weight (all) & 34 & 0.80 & -6.318 & 2.860 \\
SVL vs. weight (juveniles) & 8 & 0.97 & -6.003 & 2.754 \\
SVL vs. weight (adult males) & 10 & 0.99 & -4.961 & 2.557 \\
SVL vs. weight (adult females) & 16 & 0.73 & -5.231 & 2.623 \\
\hline
\end{tabular}

significantly from those in the late summer of 2015 $(P=0.497)$. There was also no significant difference between the distances of $M$. l. lebetina to artificial water bodies in the spring of 2014 and in the late summer of $2015(P=0.635)$. Equally, the Wilcoxon matched pairs test could not prove a significant difference between the

Table 3 Correlation coefficients (R) between morphometric characteristics of blunt-nosed vipers from Cyprus (significant $P$ values bold)

\begin{tabular}{llll}
\hline & $\mathrm{N}$ & $\mathrm{R}$ & $P_{\text {correlation }}$ \\
\hline SVL vs. TaL (all) & 33 & 0.93 & $\mathbf{0 . 0 0 0}$ \\
SVL vs. TaL (juveniles) & 8 & 0.997 & $\mathbf{0 . 0 0 0}$ \\
SVL vs. TaL (adult males) & 10 & 0.89 & $\mathbf{0 . 0 0 1}$ \\
SVL vs. TaL (adult females) & 15 & 0.58 & $\mathbf{0 . 0 2 4}$ \\
SVL vs. HL (all) & 32 & 0.97 & $\mathbf{0 . 0 0 0}$ \\
SVL vs. HL (juveniles) & 8 & 0.896 & $\mathbf{0 . 0 0 3}$ \\
SVL vs. HL (adult males) & 10 & 0.97 & $\mathbf{0 . 0 0 0}$ \\
SVL vs. HL (adult females) & 14 & 0.85 & $\mathbf{0 . 0 0 0}$ \\
SVL vs. HW (all) & 32 & 0.96 & $\mathbf{0 . 0 0 0}$ \\
SVL vs. HW (juveniles) & 8 & 0.93 & $\mathbf{0 . 0 0 1}$ \\
SVL vs. HW (adult males) & 10 & 0.93 & $\mathbf{0 . 0 0 0}$ \\
SVL vs. HW (adult females) & 14 & 0.72 & $\mathbf{0 . 0 0 4}$ \\
HL vs. HW (all) & 32 & 0.98 & $\mathbf{0 . 0 0 0}$ \\
HL vs. HW (juveniles) & 8 & 0.98 & $\mathbf{0 . 0 0 0}$ \\
HL vs. HW (adult males) & 10 & 0.93 & $\mathbf{0 . 0 0 0}$ \\
HL vs. HW (adult females) & 14 & 0.83 & $\mathbf{0 . 0 0 0}$ \\
\hline
\end{tabular}


Table 4 Results of the $t$ test for comparison of normally distributed morphometric characteristics of blunt-nosed vipers from Cyprus (significant $P$ values bold)

\begin{tabular}{llll}
\hline Measurement & $\mathrm{n}$ adult males & $\mathrm{n}$ adult females & $P$ \\
\hline SVL $(\mathrm{cm})$ & 10 & 16 & 0.060 \\
TaL $(\mathrm{cm})$ & 10 & 15 & $\mathbf{0 . 0 0 5}$ \\
ToL $(\mathrm{cm})$ & 10 & 15 & $\mathbf{0 . 0 4 7}$ \\
HL $(\mathrm{mm})$ & 10 & 14 & $\mathbf{0 . 0 1 6}$ \\
HW $(\mathrm{mm})$ & 10 & 14 & 0.087 \\
Weight $(\mathrm{g})$ & 10 & 16 & 0.097 \\
HL / SVL & 10 & 14 & 0.518 \\
HL / HW & 10 & 14 & 0.449 \\
BCl (K) & 10 & 16 & 0.216 \\
\hline
\end{tabular}

distances of M. l. lebetina to natural and artificial water bodies in the spring of 2014 $(P=0.295)$ and in the late summer of $2015(P=0.717)$.

\section{Discussion}

\section{Habitat preferences}

The summer season is a critical period for populations of M. lebetina. Female blunt-nosed vipers not only need to find suitable refuges for oviposition, incubation and clutch protection, but also must cope with postpartum weight loss. Newborn vipers face a diverse range of predators [8]. Due to their small body size, they are also more threatened by dehydration than adults [32]. Against this background, it is not surprising that Cypriot blunt-nosed vipers are often found close to freshwater $[25,33]$, particularly during the hot dry summer months [17]. Water preference has also been observed among $M$. l. turanica in Uzbekistan [34]. However, the present study could not prove a seasonal preference of $M$. l. lebetina for freshwater bodies. At the same time, the frequent observations of brown rats in all surveyed blunt-nosed viper habitats indicated sufficient prey availability in the study area. In fact, agricultural areas and other man-made landscapes with plenty of crops and organic waste offer conditions favorable to rat populations in Cyprus $[25,35,36]$, which are large [37] and may attract blunt-nosed

Table 5 Results of the Mann-Whitney $U$ test for comparison of not normally distributed morphometric characteristics of blunt-nosed vipers from Cyprus

\begin{tabular}{llll}
\hline Measurement & $\mathrm{n}$ adult males & $\mathrm{n}$ adult females & exact $P$ \\
\hline TaL / SVL & 10 & 15 & 0.285 \\
TaL / ToL & 10 & 15 & 0.285 \\
\hline
\end{tabular}

Table 6 Recorded distances of blunt-nosed vipers to the nearest water body (Paphos district, Cyprus)

\begin{tabular}{llll}
\hline Distances of blunt-nosed vipers & $\mathrm{n}$ & Range (meters) & Mean \pm SD \\
\hline $\begin{array}{l}\text { To nearest water body } \\
\text { (Spring 2014) }\end{array}$ & 19 & $3-511$ & $103.53 \pm 143.82$ \\
$\begin{array}{l}\text { To nearest natural } \\
\text { water body (Spring 2014) }\end{array}$ & 19 & $3-2111$ & $485.95 \pm 596.28$ \\
$\begin{array}{l}\text { To nearest artificial } \\
\text { water body (Spring 2014) }\end{array}$ & 19 & $10-1092$ & $211.74 \pm 248.14$ \\
$\begin{array}{l}\text { To nearest water body } \\
\text { (Summer 2015) }\end{array}$ & 17 & $0-1740$ & $181.59 \pm 416.38$ \\
$\begin{array}{l}\text { To nearest natural water } \\
\text { body (Summer 2015) }\end{array}$ & 16 & $0-2853$ & $864.50 \pm 1038.65$ \\
$\begin{array}{l}\text { To nearest artificial water } \\
\text { body (Summer 2015) }\end{array}$ & 17 & $0-2051$ & $564.24 \pm 675.22$ \\
\hline
\end{tabular}

vipers even if freshwater is not available [38]. Besides ingesting the water contained in their prey animals, vipers can survive in xeric environments by drinking water from rain showers and mists. They can also harvest water from structural features of their environment such as rock surfaces after rain, or by dorsoventrally flattening their body to collect water droplets on their skin [39-41]. Snakes can further reduce their dehydration rate via resting in a coiled instead of stretched position [32]. Habitat structures allowing for thermoregulation and thermal protection have been proven critical for $M$. l. obtusa, and bluntnosed vipers do not inhabit areas lacking these features [42]. In our current study, structural diversity in all surveyed habitats indicated an abundance of microhabitats providing shelter, humidity and thermoregulation to blunt-nosed vipers, also in areas void of freshwater bodies during summer. A 1993-1998 radio-telemetry study of the Cyclades blunt-nosed viper (Macrovipera schweizeri), now considered a subspecies of M. lebetina [43], found that this snake was not primarily attracted to water bodies but to structures that attracted their avian prey. These structures changed from water pools in spring to trees in autumn, when the pools had dried out. In both seasons, stream beds with riparian vegetation were important. M. schweizeri was absent from biotopes without large bushes as well as from densely vegetated habitats [44]. Our findings suggest that prey availability and protective microhabitat structures such as large bushes and rocks are critically important for preserving Cypriot blunt-nosed viper populations, whereas the annual drying out of water bodies in late summer does not seem to prevent $M$. l. lebetina from inhabiting areas. However, droughts have become more frequent on Cyprus [17], and their long-term impact on Cypriot snake species has not 
yet been studied (S. Zotos pers. comm. 12 March 2018).

\section{Shedding sites}

Shedding increases dehydration in snakes [32]. As Cypriot blunt-nosed vipers slough four times a year, with two sloughings taking place during the summer months [17], the selection of suitable shedding sites is an important decision for the healthy development of $M$. l. lebetina throughout the year. Prior to molting, blunt-nosed vipers seek contact with water by bathing or lying in the rain to facilitate the sloughing of the old skin [8]. Water bodies may thus be particularly attractive for $M$. l. lebetina in pre-shed condition and may influence the selection of shedding locations, together with other factors (e.g. prey availability) that are communicated via chemical cues. The two blunt-nosed viper sloughs recorded in early April 2014 and late September 2015 were situated in habitats with year-round water availability, diversity of microstructures and abundance of brown rats. Based on observations of North American rattlesnakes (Crotalus oreganus), Loughran et al. (2015) pointed out that different social interactions (e.g., pairing and mating) occurred around shedding sites and that these places had a similar importance for the social structure of snakes as communal hibernacula [45]. This implies that water bodies are potentially important for facilitating interspecific contact in snakes, particularly in more arid environments such as Cyprus.

\section{Home range}

Even though no data on $M$. l. lebetina movements are available, distances of $2-3 \mathrm{~km}$ to water bodies (as recorded for some individuals during this survey) may still fall within the home range of this species. Nilson et al. (1999) found that the home range of the smaller M. schweizeri was up to 20 ha, with one female covering a distance of $5 \mathrm{~km}$ within 12 months [44]. A radio-telemetry study in Cyprus would be highly useful for obtaining more precise information about $M$. $l$. lebetina habitat use.

\section{Artificial and natural water bodies}

The annual drying-up of many natural water bodies in summer may imply that Cypriot blunt-nosed vipers prefer man-made, permanent water bodies during this season, but not necessarily during the rainier spring. Yet this study could neither confirm a preference for artificial over natural water bodies during late summer, nor could it provide evidence that vipers are found closer to artificial water bodies in late summer than in spring. These findings indicate that swimming pools are not more attractive for $M$. l. lebetina than natural pools during late summer, highlighting the importance of natural water bodies for blunt-nosed viper conservation. Since water bodies provide significant advantages for blunt-nosed vipers such as ambushing for prey [17], water uptake and thermoregulation during heat periods, swimming pool users still face an increased risk of viper encounters during summer. The viper bite incident in Latchi in September 2015 highlights the necessity of adequate protection measures. These include illuminating the entire pool area after sunset, wearing protective footwear, and cleaning debris from the surroundings, as blunt-nosed vipers (especially juveniles) may hide underneath larger, flat-surfaced objects such as wooden boards and flower pots (pers. obs.). Vipers can be kept away from properties by solid fences whereas nets will indiscriminately kill various species of reptiles and other wildlife by entanglement [46]. The idea of developing effective snake repellents is promising, but commercially available chemicals such as naphthalene and sulfur have not proven effective in field trials [47].

\section{Anthropogenic impact and conservation}

The ongoing anthropogenic destruction of wild snake habitats for real-estate and industrial development in Cyprus [17] may threaten the survival of wild M. l. lebetina populations and increase the likelihood of human-viper confrontations in the future. Habitat loss due to land transformation for tourism is a general threat to snake species on Eastern Mediterranean islands [48]. Wildfires, which regularly occur in Cyprus, may render habitats unsuitable for snakes and their prey organisms (e.g. birds) for up to 10 years. Together with surface mining, wildfires are a major threat to blunt-nosed viper habitats on the island of Milos [44]. Road traffic is a threat to M. lebetina throughout the species' range [8].

Although M. l. lebetina is listed in Appendix II of the Berne convention (which contains "strictly protected fauna species"), it is the only snake species not protected by law in Cyprus [17], but at the same time the most pursued one. As all surveyed water bodies were checked at least monthly by mosquito control workers, the local viper populations were exposed to continuous anthropogenic pressure (Fig. 3d). This ongoing human encroachment of riparian habitats coupled with the consequent killing of blunt-nosed vipers may greatly reduce their populations along streams and can be regarded as another major threat to the species in Cyprus (H.-J. Wiedl pers. comm. 29 March 2014). Pursuit by hunters must be considered as a significant threat, too. In Cyprus, feral cats commonly prey on reptiles, including Laudakia stellio and Dolichophis jugularis [17]. Feral cat predation on young vipers also poses a threat to the reproduction of $M$. schweizeri on Milos [44]. Consequently, their impact on M. l. lebetina should be investigated. 
Workshops for mosquito control workers and other (occupational) outdoor groups such as hunters, shepherds, farmers, forestry employees and game wardens could help to raise awareness of non-lethal methods of preventing human-viper conflict such as snake deterrence or translocation. Workshops should also be offered to rural communities and schools. Public education could be further aided by the establishment of a national snakebite database for Cyprus, which so far is not available (E. Erotokritou pers. comm. 12 October 2017). Valuable snake habitats such as wild riparian areas and rocky slopes with confirmed populations of M. l. lebetina should be placed under protection, with prohibition of land transformation (e.g., for real-estate development), and strict regulations concerning further interventions by man (e.g., grazing). This could be achieved by designating new areas for the Natura 2000 network of the European Union. In all conservation areas, hunting should be prohibited. Wetlands are also important habitats of other endangered Cypriot reptiles such as Hierophis cypriensis (Cyprus whip snake), Natrix natrix cypriaca (grass snake) and Mauremys rivulata (Balkan terrapin) [17].

\section{Allometric relationship between snout-vent length and weight}

The allometric relationship between SVL and weight in M. l. lebetina $(n=34)$ can be modelled as an exponential curve (Fig. 7) fitted to the scatterplot of SVL vs. weight. According to the equation, a very large Cypriot bluntnosed viper of $135 \mathrm{~cm} \mathrm{SVL}$ would weigh $2227 \mathrm{~g}$, which is not far from the reported maximum body weight of mainland blunt-nosed vipers according to Ščerbak \&
Böhme (2005): $2700 \mathrm{~g}$ for males and $2000 \mathrm{~g}$ for females [8]. However, Sochurek (1979) reports that he obtained a large male blunt-nosed viper of more than $3 \mathrm{~kg}$ body weight from the USSR around the year 1950 [49]. Out of 23 blunt-nosed vipers collected in Iran (Khorasan province), the heaviest male (SVL $125.5 \mathrm{~cm}, \mathrm{TaL} 17.0 \mathrm{~cm}$ ) and female (SVL $113.0 \mathrm{~cm}$, TaL $14.0 \mathrm{~cm}$ ) each weighed $1180 \mathrm{~g}$ ([50], A. Nasoori pers. comm. 15 January 2018). While Cypriot blunt-nosed vipers can reach a ToL of $150 \mathrm{~cm}$ [17], mainland subspecies (e.g., M. l. obtusa) may grow up to $218 \mathrm{~cm} \mathrm{[51];} \mathrm{however,} \mathrm{one} \mathrm{individual} \mathrm{of} 230 \mathrm{~cm}$ was recorded [18]. Bannikov et al. (1977) state a maximum ToL of $160 \mathrm{~cm}$ [52], whereas Sochurek (1979) mentions specimens of up to $190 \mathrm{~cm}$ ToL [49].

\section{Variability of body condition}

The highest coefficient of variation among all variables in this study was determined for weight (from $46 \%$ in adult females to $113 \%$ in juveniles). It corresponds to the identified positive allometric relationship between weight and the linear measures of the blunt-nosed viper's body. The relatively low $R^{2}$ determination coefficient of the regression ln weight vs. In SVL among adult female blunt-nosed vipers (0.73) shows that the body weight of females was not only influenced by their SVL but also by other factors. In line with our hypothesis, adult $M$. $l$. lebetina females caught in September were significantly thinner than those captured in spring $(P=0.001)$. This fluctuation of body mass might be explained by postpartum weight loss, provided that the females examined in late summer had reproduced in that year. After

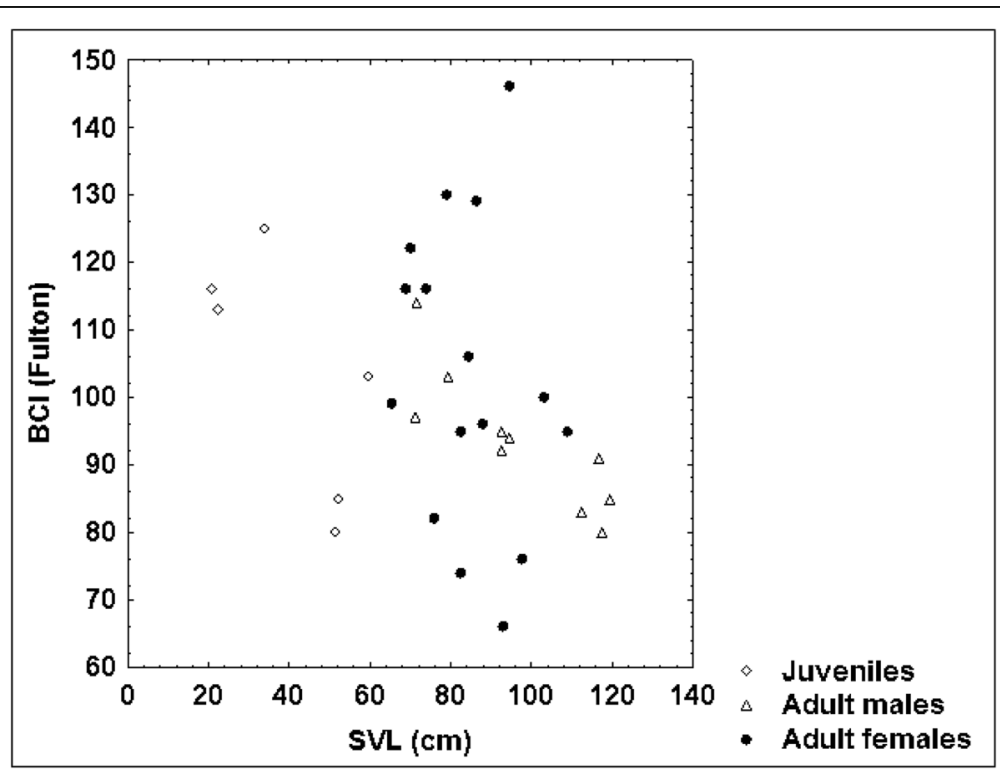

Fig. 8 Relationship between SVL and body condition index (BCI) in 34 blunt-nosed vipers from Cyprus: $R=0.40$ 
oviposition, blunt-nosed vipers (M. l. obtusa) may lose up to $52 \%$ of their weight (mean: $35 \%$ ) [53]. Snake body condition is also influenced by the size and time of the last meal, and by diseases or parasites. Adult male bluntnosed vipers are more likely to thrive during late summer than during spring, as they neither have to search for females nor engage in combat with male rivals anymore [17]. However, the low number of adult males recorded during this study in late summer (three compared to seven males in spring) prevented a seasonal comparison within males. Although our sample of adult male vipers was small $(n=10)$, the significantly lower body condition index of the four largest adult males compared to the six smaller ones was striking $(P=0.013)$, since it suggests that male blunt-nosed vipers may become thinner with age. This hypothesis would be consistent with the trend of the scatterplot of SVL vs. BCI (Fig. 8) showing that the highest $\mathrm{BCI}$ values were observed among small and medium-sized vipers $(\mathrm{SVL}<100 \mathrm{~cm})$. Large blunt-nosed vipers may lose weight due to the accumulation of endoparasites in snakes with increasing age, and the consequent loss of appetite and weight [54-56]. Zinyakova (1967) detected 25 species of endoparasites in $M$. l. turanica from the Soviet Union [57], while Murvanidze et al. (2008) listed seven species of helminths inhabiting Georgian $M$. l. obtusa [58]. Of 20 Iranian blunt-nosed vipers (M. l. obtusa) examined by Nasiri et al. (2014), 16 were infested with parasites [59]. As our sample included only two females exceeding $100 \mathrm{~cm}$ SVL, a comparison between larger and smaller adult females was impossible (14:2 ratio). Our findings indicate that adult female blunt-nosed vipers are in a more vulnerable physical condition in late summer than in spring, and that old age possibly has an adverse effect on the body condition index of $M$. l. lebetina. However, a much larger dataset is needed to provide solid statistical evidence.

\section{Sex-specific differences}

Although we could not prove that adult male blunt-nosed vipers exceeded adult females in body size and weight ( $P$-values of the respective $\mathrm{t}$ test amounted to 0.06 for SVL and 0.097 for weight), our results suggested that they were longer and heavier. This apparent dimorphism was further supported by the significantly longer TaL $(P=0.005)$, ToL $(P=0.047)$ and HL $(P=0.016)$ of adult males. This trend is also shown by the scatterplots of SVL vs. TaL (Fig. 9), SVL vs. HL (Fig. 10) and HL vs. HW (Fig. 11). As the ratio of TaL to SVL and of TaL to ToL in adult individuals was not significantly different between sexes, we could not confirm our hypothesis that males had shorter tails than females (see [17]). This indicates that sex-specific morphological differences in $M$. l. lebetina are still a controversial issue. However, our findings of the ratio TaL / ToL were similar to those of other authors [50], who recorded a mean ratio of $11.89 \pm 1.56 \%$ among 15 adult males (our study: $11.85 \pm 1.18 \%$ ) and a mean ratio of $11.10 \pm 0.59 \%$ in eight adult females of Iranian M. l. obtusa (our study: $10.80 \pm 1.91 \%$ ). Larger sample sizes are required to obtain more powerful test results on sex-specific differences.

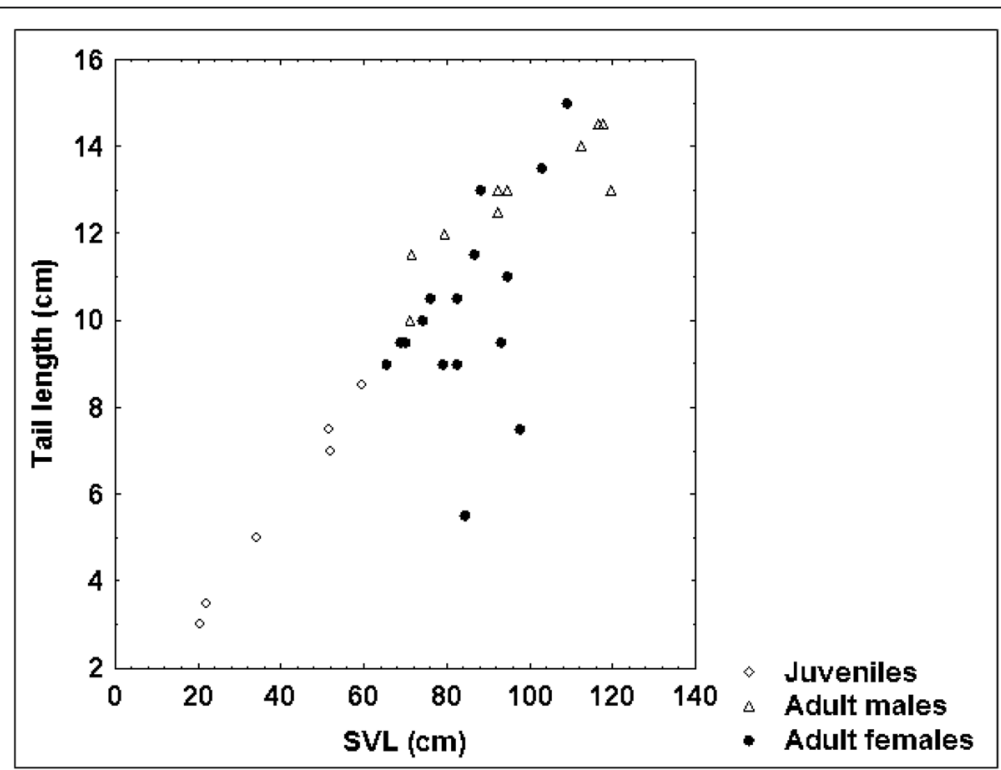

Fig. 9 Relationship between SVL and TaL in 34 blunt-nosed vipers from Cyprus: $R=0.89$ 


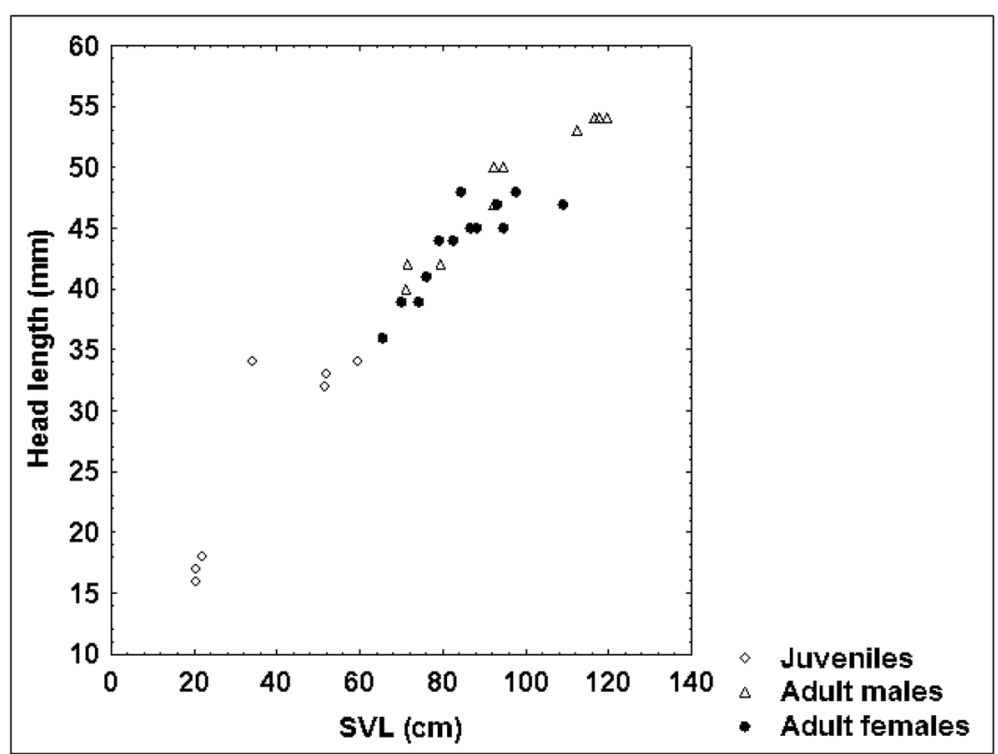

Fig. 10 Relationship between SVL and HL in 32 blunt-nosed vipers from Cyprus: $R=0.97$

\section{Size comparison with other large Holarctic vipers}

The enormous differences in body size between blunt-nosed vipers from the Cyclades and Cyprus $[8,17,44,60]$ demonstrate the morphological variability within $M$. lebetina. It is the only European viper reaching $150 \mathrm{~cm}$ ToL and $2000 \mathrm{~g}$ body mass (or more), which is comparable to the body dimensions of large North American rattlesnake species (Crotalus spp.) (Table 7). Some of the latter (e.g., C. atrox) are found in similar biomes (dry steppe, semiarid desert) as M. lebetina. In the Mediterranean basin, Moorish vipers (Daboia mauritanica) and desert vipers $(D$. deserti) reach similar dimensions $(180 \mathrm{~cm}$ and $160 \mathrm{~cm}$ maximum ToL, respectively), whereas Palestine (D. palaestinae) and Ottoman vipers (Montivipera xanthina) commonly do not grow much larger than $1 \mathrm{~m}$ [61]. However, exceptionally long individuals may reach $136 \mathrm{~cm}$ ToL (1227 g body mass) in D. palaestinae (S. Meiri pers. comm. 1 May 2017) and $143.5 \mathrm{~cm}$ ToL

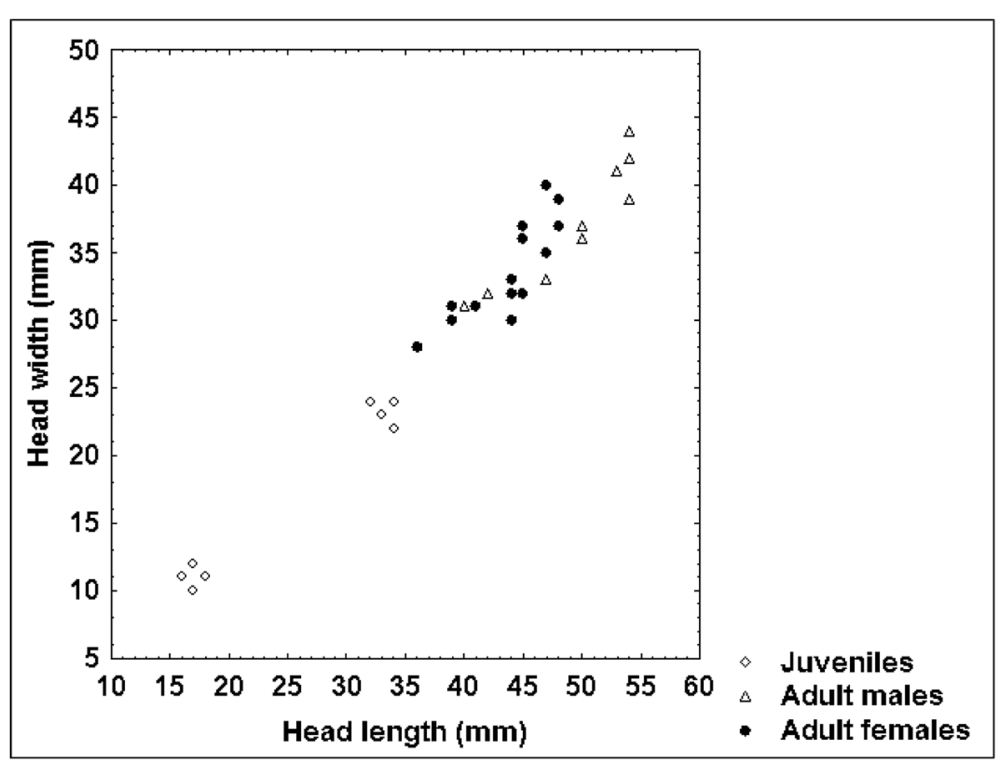

Fig. 11 Relationship between $H \mathrm{~L}$ and HW in 32 blunt-nosed vipers from Cyprus: $R=0.98$ 
Table 7 Snout-vent length, weight and body condition index (BCI) of M. I. lebetina compared to large North American rattlesnake species (Crotalus spp., USA)

\begin{tabular}{|c|c|c|c|c|c|}
\hline \multicolumn{6}{|c|}{ General information $[31,61]$} \\
\hline Scientific name & M. lebetina & C. adamanteus & C. atrox & C. horridus & C. oreganus \\
\hline Common name & Blunt-nosed viper & $\begin{array}{l}\text { Eastern diamondback } \\
\text { rattlesnake }\end{array}$ & $\begin{array}{l}\text { Western diamondback } \\
\text { rattlesnake }\end{array}$ & Timber rattlesnake & Western rattlesnake \\
\hline Distribution & $\begin{array}{l}\text { Eurasia to Central } \\
\text { and South Asia }\end{array}$ & Southeastern USA & $\begin{array}{l}\text { Southwestern North } \\
\text { America }\end{array}$ & $\begin{array}{l}\text { Eastern to Central } \\
\text { USA }\end{array}$ & $\begin{array}{l}\text { Western North } \\
\text { America }\end{array}$ \\
\hline $\begin{array}{l}\text { Maximum ToL } \\
(\mathrm{cm})\end{array}$ & $\begin{array}{l}150 \text { (Cyprus); } \\
218-230 \text { (mainland) }\end{array}$ & 244 & 213 & 189 & 163 \\
\hline \multicolumn{6}{|l|}{ Specimen data } \\
\hline Origin & Wild, Cyprus & Captive, North Carolina & Wild, Oklahoma & Wild, Virginia & Wild, California \\
\hline SVL (cm) & 116.5 & 168.8 & 152.0 & 140.7 & 109.0 \\
\hline TaL (cm) & 14.5 & 16.0 & - & 11.3 & 9.0 \\
\hline Weight (g) & 1441 & 4850 ("4.85 kg") & 2776 & 3509 & 1150 \\
\hline $\mathrm{BCl}(\mathrm{K})$ & 91 & 101 & 79 & 126 & 89 \\
\hline Reference & This study & [63] & [64] & $\begin{array}{l}\text { S. Goetz pers. comm. } \\
29 \text { January } 2018\end{array}$ & $\begin{array}{l}\text { B. Putman pers. comm. } \\
19 \text { January } 2018\end{array}$ \\
\hline
\end{tabular}

(1284 g body mass) in M. xanthina nilsoni ([62]; A. Cattaneo pers. comm. 2 August 2017). Maximum recorded body weights of $D$. palaestinae were $1640 \mathrm{~g}(131 \mathrm{~cm}$ ToL) and $1800 \mathrm{~g}(128 \mathrm{~cm}$ ToL), respectively, the latter being a gravid female (S. Meiri, unpublished data). As large viper species are primarily found in the Americas, Africa, the Middle East and South Asia, the enormous body dimensions of $M$. l. lebetina highlight its morphological and evolutionary uniqueness within the European viper fauna.

\section{Conclusions}

We conclude that adult males of $M$. l. lebetina exceed adult females in head length, tail length and total length. Adult female blunt-nosed vipers are probably in a more vulnerable physical condition in late summer than in spring. Old age possibly has an adverse effect on the body condition index of $M$. l. lebetina. The annual drying out of freshwater bodies in late summer most likely is not a decisive factor for the occurrence of the species on Cyprus. It must be assumed that prey availability and protective microhabitat structures such as large bushes and rocks are of crucial importance for preserving blunt-nosed viper populations in Cyprus. A radio-telemetry study would greatly improve the understanding of the spatial ecology of $M$. l. lebetina. Workshops should be conducted for rural communities, schools and outdoor groups to raise awareness of non-lethal ways of removing blunt-nosed vipers from areas inhabited or frequented by people. The establishment of a national snakebite database for Cyprus would contribute to improving public education. Wild snake habitats with confirmed populations of $M . l$. lebetina should be protected from anthropogenic modifications such as real-estate development, grazing and hunting.

\section{Abbreviations \\ ${ }^{\circ} \mathrm{C}$ : Degrees Celsius; ${ }^{\circ} \mathrm{E}$ : Eastern latitude; ${ }^{\circ} \mathrm{N}$ : Northern latitude; AM: Time before noon; BCl (K): Fulton's body condition index; $\mathrm{cm}$ : Centimeters; CV: Coefficient of variation; Fig.: Figure; g: Grams; HL / HW: Ratio of head length to head width; HL / SVL: Ratio of head length to snout-vent length; HL: Head length; HW: Head width; kg: Kilograms; m: Meters; mm: 1) millimeters of length, 2) millimeters of precipitation; $\mathrm{n}$ : Sample size; $P$ : Probability value; PM: Time after noon; $R$ : Correlation coefficient; $R^{2}$ : Coefficient of determination; SD: Standard deviation; SVL: Snout-vent length; TaL / SVL: Ratio of tail length to snout-vent length; TaL / ToL: Ratio of tail length to total length; TaL: Tail length; ToL: Total length; W: Weight in grams}

\section{Acknowledgements}

We acknowledge support by the German Research Foundation and the Open Access Publication Fund of Göttingen University. Also, we thank Ulrich Joger, Stefan Schütz, Spyros Sfenthourakis, Savvas Zotos, Nikolaus Stümpel, Volker Schrempf, Hans-Jörg Wiedl, Felix Baier, Ulrich Kuch and Frank Gessler for insightful discussions and encouragement. We are immensely grateful to Elena Erotokritou and Elena Stylianopoulou (Department of Environment, Cyprus) for granting research permits. Great thanks also go to Elias Christodoulou and his family for their hospitality during the visits of DJ to Cyprus. The fieldwork was kindly supported by Volker Schrempf, Hans-Jörg Wiedl, Marios and Periklis Theodorou, Savvas Zotos, Elena Erotokritou, Haris Nicolaou, Spyros Sfenthourakis, Caroline Penman, Chandani Ekanayaka, Eftichia Demetriade, Konrad Mebert, Demetris Christofi, Fidias Charalambous, Demetris Pavlou, Pawel Sikorski, Stelios Paphitis, Harris Demetriades and Koula Michael, as well as by Christaki and Lucy (Peristerona), and the interview partners in Cyprus. Many thanks go to Takis Tsintides for the determination of plant species and to Joachim Jenrich, who analyzed all blunt-nosed viper stomach contents. Verena Tobert helped with the transport of samples. We are indebted to Shai Meiri for sharing morphological data of $D$. palaestinae and to Augusto Cattaneo for morphological data of M. xanthina nilsoni. We also thank Ali Nasoori (M. lebetina), Breanne Putman (C. oreganus oreganus), George Pisani (C. atrox), Rulon Clark and Scott Goetz (C. horridus) for further specimen data. Additional information on blunt-nosed vipers was provided by Mario Schweiger, Dieter Glandt and André Schmidt. 


\section{Funding}

The fieldwork in Cyprus was generously supported by the Mohamed bin Zayed Species Conservation Fund, the German Society for Herpetology and Herpetoculture (via the Hans-Schiemenz Fonds), the Department of Forest Zoology and Forest Conservation (University of Göttingen) and the Nature and Biodiversity Conservation Union (NABU, Germany).

\section{Availability of data and materials}

The datasets generated and analyzed during this study are available from the corresponding author upon reasonable request.

\section{Authors' contributions}

DJ designed the study, carried out the fieldwork and discussed the results with IK, who also conducted the statistical analysis. Both authors wrote, read and approved the manuscript.

\section{Ethics approval and consent to participate}

Approval for this study was granted by the Department of Environment of Cyprus (Ministry of Agriculture, Rural Development and Environment; Reference number 02.15.001.003, 04.05.2002.005.006).

\section{Consent for publication}

Not applicable.

\section{Competing interests}

The authors declare that they have no competing interests.

\section{Publisher's Note}

Springer Nature remains neutral with regard to jurisdictional claims in published maps and institutional affiliations.

\section{Author details}

${ }^{1}$ Faculty of Forest Sciences and Forest Ecology, Department of Forest Zoology and Forest Conservation, University of Göttingen, Büsgenweg 3, 37077 Göttingen, Germany. ${ }^{2}$ Faculty of Forest Sciences and Forest Ecology, Department of Ecoinformatics, Biometrics and Forest Growth, University of Göttingen, Büsgenweg 4, 37077 Göttingen, Germany.

Received: 11 June 2018 Accepted: 30 November 2018 Published online: 27 December 2018

\section{References}

1. Corkill NL. Snakes of Iraq. J Bombay Nat Hist Soc. 1932;35(3):552-72.

2. Stümpel $N$, Joger $U$. Recent advances in phylogeny and taxonomy of near and middle eastern vipers - an update. In: Neubert E, Amr Z, Taiti S, Gümüs $B$, editors. Animal biodiversity in the Middle East: proceedings of the first middle eastern biodiversity congress; 20-23 October 2008. Aqaba: Jordan. ZooKeys; 2009. p. 179-91.

3. Cesaretli Y, Ozkan O. Snakebites in Turkey: epidemiological and clinical aspects between the years 1995 and 2004. J Venom Anim Toxins incl Trop Dis. 2010;16(4):579-86 http://www.scielo.br/scielo.php?script=sci_ arttext\&pid=S1678-91992010000400007.

4. Sagheb MM, Sharifian M, Moini M, Salehi O. Acute renal failure and acute necrotizing pancreatitis after Echis carinatus sochureki bite, report of a rare complication from Southern Iran. Prague Med Rep. 2011;112(1):67-71.

5. Dehghani $R$, Mehrpour $O$, Shahi MP, Jazayeri M, Karrari P, Keyler D, et al. Epidemiology of venomous and semi-venomous snakebites (Ophidia: Viperidae, Colubridae) in the Kashan city of the Isfahan province in Central Iran. J Res Med Sci. 2014;19(1):33-40.

6. Swaroop S, Grab B. Snakebite mortality in the world. Bull World Health Organ. 1954;61:949-56.

7. Hopkins GO. Snake bites in Cyprus. J R Army Med Corps. 1974;120:19-23.

8. Ščerbak N, Böhme W. Macrovipera lebetina (Linnaeus, 1758) - Levante-otter In: Joger U, Stümpel N, editors. Handbuch der Reptilien und Amphibien Europas. Band 3/IIB, Schlangen III. Wiesbaden: Aula-Verlag; 2005. p. 25-42.

9. Sharma LR, Lal V, Simpson ID. Snakes of medical significance in India: the first reported case of envenoming by the Levantine viper (Macrovipera lebetina). Wilderness Environ Med. 2008;19(3):195-8.

10. Phelps T. Old world vipers. A natural history of the Azemiopinae and Viperinae. Frankfurt am Main: Edition Chimaira; 2010.
11. Göçmen B, Arikan H, Ozbel Y, Mermer A, Çiçek K. Clinical, physiological and serological observations of a human following a venomous bite by Macrovipera lebetina lebetina (Reptilia: Serpentes). Turkiye Parazitol Derg. 2006:30(2):158-62

12. Bazaa A, Marrakchi N, El Ayeb M, Sanz L, Calvete JJ. Snake venomics: comparative analysis of the venom proteomes of the Tunisian snakes Cerastes cerastes, Cerastes vipera and Macrovipera lebetina. Proteomics. 2005; 5(16):4223-35.

13. Park MH, Jo M, Won D, Song HS, Han SB, Song MJ, et al. Snake venom toxin from Vipera lebetina turanica induces apoptosis of colon cancer cells via upregulation of ROS- and JNK-mediated death receptor expression. BMC Cancer. 2012;12:228.

14. Nalbantsoy A, Karabay-Yavasoglu NU, Sayım F, Deliloglu-Gurhan I, Göçmen $\mathrm{B}$, Arıkan $\mathrm{H}$, et al. Determination of in-vivo toxicity and in-vitro cytotoxicity of venom from the Cypriot blunt-nosed viper Macrovipera lebetina lebetina and antivenom production. J Venom Anim Toxins incl Trop Dis. 2012;18(2): 208-16 http://www.scielo.br/scielo.php?script=sci_arttext\&pid=S167891992012000200011

15. Ozen MO, İğci N, Yalçin HT, Göçmen B, Nalbantsoy A. Screening of cytotoxic and antimicrobial activity potential of Anatolian Macrovipera lebetina obtusa (Ophidia: Viperidae) crude venom. Front Life Sci. 2015;8(4):363-70.

16. Suzergoz F, Ĭğci N, Çavuş C, Yildiz MZ, Coşkun MB, Göçmen B. In vitro cytotoxic and proapoptotic activities of Anatolian Macrovipera lebetina obtusa (Dwigubski, 1832) crude venom on cultured K562 human chronic myelogenous leukemia cells. Int J Hematol Oncol. 2016;26(1):37-46.

17. Baier F, Sparrow DJ, Wiedl HJ. The amphibians and reptiles of Cyprus. Frankfurt am Main: Edition Chimaira; 2013.

18. Mermer A, Göçmen B, Çiçek K. Extreme cases of colour pattern and size in Levantine viper, Macrovipera lebetina (L., 1758) from the west of Euphrates Basin (southern Anatolia, Turkey). Biharean Biol. 2012;6(1):70-1.

19. Gruber U. Die Schlangen Europas und rund ums Mittelmeer. Stuttgart: Franckh'sche Verlagshandlung; 1989.

20. Feldman A, Meiri S. Length-mass allometry in snakes. Biol J Linn Soc. 2013; 108:161-82.

21. Băncilă Rl, Hartel T, Plăiașu R, Smets J, Cogălniceanu D. Comparing three body condition indices in amphibians: a case study of yellow-bellied toad Bombina variegata. Amphib Reptil. 2010;31(4):558-62.

22. Sahlean TC, Strugariu A, Dincă PC, Chișamera G, Stanciu CR, Zamfirescu SR, et al. Morphological characteristics of the elusive blotched snake (Elaphe sauromates) at its northwestern range limit (Romania). Turkish J Biol. 2016; 40(1):136-40.

23. Tsairi H, Bouskila A. Ambush site selection of a desert snake (Echis coloratus) at an oasis. Herpetologica. 2004;60(1):13-23.

24. García-Cardenete L, Pleguezuelos JM, Brito JC, Jiménez-Cazalla F, PérezGarcía MT, Santos X. Water cisterns as death traps for amphibians and reptiles in arid environments. Environ Conserv. 2014;41:341-9.

25. Kabisch K, Wiedl HJ. Zur Levanteotter, Macrovipera lebetina lebetina (Linnaeus, 1758) auf Zypern. Sauria. 2009;30(4):29-36

26. Constantinides G. Coastal area management Programme Cyprus: diagnostic - feasibility report. Nicosia: Prepared for MAP - PAP/RAC; 2002.

27. Delipetrou P, Makhzoumi J, Dimopoulos P, Georghiou K. Cyprus. In: Vogiatzakis I, Pungetti G, Mannion AM, editors. Mediterranean Island landscapes - natural and cultural approaches. Berlin: Springer; 2008. p. 170203.

28. Climatological data, Polis, 1991-2005. Cyprus Department of Meteorology, Nicosia. - [cited 24 May 2018]. Available from: http://www.moa.gov.cy/moa/ MS/MS.nsf/All/FD3278466EACCF9FC22576C80036B9DF/\$file/ Climatological\%20Data_1991_2005_Polis\%20Chrysochous_U.K. pdf?Openelement.

29. Shine R, Webb JK, Fitzgerald M, Sumner J. The impact of bush-rock removal on an endangered snake species, Hoplocephalus bugaroides (Serpentes: Elapidae). Wildl Res. 1998;25(3):285-95.

30. Benson PA. Identifying individual adders, Vipera berus, within an isolated colony in East Yorkshire. Herpetol Bull. 1999;67:21-7.

31. Klauber LM. Rattlesnakes: their habits, life histories, and influence on mankind. 2nd ed. Berkeley and Los Angeles: University of California Press; 1972.

32. Cohen AC. Some factors affecting water economy in snakes. Comp Biochem Physiol. 1975;51A:361-8.

33. Osenegg K. Die Amphibien und Reptilien der Insel Zypern [diploma thesis]. Bonn: University of Bonn; 1989. 
34. Cherlin VA, Shepilov SA. Thermal biology of the central Asian blunt-nosed viper (Macrovipera lebetina turanica) from Nuratau crest and the Chernov blunt-nosed viper (Macrovipera lebetina černovi) from Western Kysylkum. Biol Bull. 2014;41(8):639-44.

35. Watson J. The rat problem in Cyprus, Col. Res. Publ. 1951;9:1-66.

36. Davies WNL. The carob tree and its importance in the agricultural economy of Cyprus. Econ Bot. 1970;24:460-70.

37. Psaroulaki A, Antoniou M, Toumazos P, Mazeris A, loannou I, Chochlakis D, et al. Rats as indicators of the presence and dispersal of six zoonotic microbial agents in Cyprus, an island ecosystem: a seroepidemiological study. Trans R Soc Trop Med Hyg. 2010;104(11):733-9.

38. Manteuffel D. Bericht über Reptilienfunde in der Türkei. Salamandra. 1993; 28(3-4):223-30.

39. Saint-Girons H. Physiologie. In: Bauchot R, editor. Schlangen. Augsburg: Weltbild Verlag; 1994. p. 76-91.

40. Repp RA, Schuett GW. Western diamond-backed rattlesnake, Crotalus atrox (Serpentes: Viperidae), gain water by harvesting and drinking rain, sleet, and snow. Southwest Nat. 2008:53:108-14

41. Glaudas X. Rain-harvesting by the southwestern speckled rattlesnake (Crotalus mitchellii pyrrhus). Southwest Nat. 2009;54(4):518-21.

42. Iskenderov TM, Javadov SA. Some aspects of thermobiology of the south Caucasian Gyurza (Macrovipera lebetina obtusa Dwigubsky, 1832). J Entomol Zool Stud. 2013;4(5):960-3.

43. Stümpel N. Phylogenie und Phylogeographie eurasischer Viperinae unter besonderer Berücksichtigung der orientalischen Vipern der Gattungen Montivipera und Macrovipera [dissertation]. Braunschweig: Braunschweig University of Technology; 2012.

44. Nilson G, Andrén C, loannidis Y, Dimaki M. Ecology and conservation of the Milos viper, Macrovipera schweizeri (Werner, 1935). Amphib Reptil. 1999;20(4): 355-75.

45. Loughran $\mathrm{CL}$, Beck DD, Weaver RE. Use of communal shedding sites by the northern pacific rattlesnake (Crotalus oreganus oreganus) in Central Washington state. Northwest Nat. 2015;96(2):156-60.

46. Ferronato $\mathrm{BO}$, Roe $\mathrm{JH}$, Georges $\mathrm{A}$. Reptile bycatch in a pest-exclusion fence established for wildlife reintroductions. J Nat Conserv. 2014;22(6):577-85.

47. Ferraro DM. The efficacy of naphthalene and sulfur repellents to cause avoidance behavior in the plains garter snake. In: Masters RE, Huggins JG, editors. Twelfth Great Plains wildlife damage control workshop proceedings; Tulsa, Oklahoma. Ardmore (Oklahoma): Noble Foundation; 1995. p. 116-20.

48. Nichol J. Bites and stings. The world of venomous animals. Newton Abbot David \& Charles; 1989.

49. Sochurek E. Kritische Liste der Giftschlangen Europas mit Beschreibung einer neuen Unterart. Mitt Zool Ges Braunau. 1979;3(8-9):213-8.

50. Nasoori A, Taghipour A, Shahbazzadeh D, Aminirissehei A, Moghaddam S. Heart place and tail length evaluation in Naja oxiana, Macrovipera lebetina, and Montivipera latifii. Asian Pac J Trop Med. 2014;7:S137-42.

51. Herrmann HW, Joger U, Nilson G. Phylogeny and systematics of viperine snakes. III: resurrection of the genus Macrovipera (Reuss, 1927) as suggested by biochemical evidence. Amphib Reptil. 1992;13(4):375-92.

52. Bannikov AG, Darevsky IS, Išeenko VG, Rustamov AK, Ščerbak NN. Opredelitel zemnovodnikh i presmikajuschikhsya fauni SSSR. Moscow: Prosveschenie; 1977.

53. Korneva LG. The reproduction of Vipera lebetina. Zool Zh. 1972;51:462-4.

54. Lenz S. Beobachtungen zum Paarungsverhalten und zum Parasitenbefall der Puffotter (Bitis arietans) in Gambia/Westafrika. Salamandra. 1994;30(1):86-9.

55. Junker K, Lane EP, Dlamini B, Kotze A, Boomker J. Post mortem identification of Kalicephalus colubri colubri (Nematoda: Diaphanocephalidae) in a captive mole snake (Pseudapis cana) in South Africa. J S Afr Vet Assoc. 2009;80(1):54-6.

56. Kavitha KT, Latha BR, Bino Sundar ST, Jayathangaraj MG, Senthil Kumar K, Sridhar R, et al. Kalicephalus sp. in a captive Russell's viper: a case report. J Parasit Dis. 2013;38(3):293-6.

57. Zinyakova MP. Rasprostanenie, ecologia gurzi (Vipera lebetina turanica Černov) i soderzanie eje v serpentarii. Tashkent: FAN; 1967.

58. Murvanidze L, Lomidze TS, Nikolaishvili K, Jankarashvili E. The annotated list of reptile helminths of Georgia. In: Bakhtadze Gl, Beltadze N, Bukhnikashvili A, Eliava IJ, Japoshvili G, Kvavadze S, Melashvili NO, Murvanidze M, Tarkhnishvili ED, editors. Proceedings of the Institute of Zoology, volume XXIII; 2008; Tbilisi, Georgia. Tbilisi: Universal; 2008. p. 54-61.

59. Nasiri V, Mobedi I, Dalimi A, Mirakabadi AZ, Ghaffarifar F, Teymurzadeh S, et al. A description of parasites from Iranian snakes. Exp Parasitol. 2014;147:7-15.
60. Nilson G. Macrovipera schweizeri (WERNER, 1935) - Kykladenviper. In: Joger U, Stümpel N, editors. Handbuch der Reptilien und Amphibien Europas. Band 3/IIB, Schlangen III. Wiesbaden: Aula-Verlag; 2005. p. 43-59.

61. Trutnau L. Giftschlangen. Schlangen im terrarium - band 2. Stuttgart: Verlag Eugen Ulmer; 1998.

62. Cattaneo A. Variabilita e sottospecie di Montivipera xanthina (Gray, 1849) nelle isole egee orientali (Reptilia Serpentes Viperidae). Nat sicil. 2014;38:51-83.

63. Palmer WA, Braswell AL. Reptiles of North Carolina. Chapel Hill (North Carolina): University of North Carolina Press; 1995.

64. Fitch HS, Pisani GR. Life history traits of the western diamondback rattlesnake (Crotalus atrox) studied from roundup samples in Oklahoma. Occ Pap Mus Nat Hist Univ Kansas. 1993;156:1-24.
Ready to submit your research? Choose BMC and benefit from:

- fast, convenient online submission

- thorough peer review by experienced researchers in your field

- rapid publication on acceptance

- support for research data, including large and complex data types

- gold Open Access which fosters wider collaboration and increased citations

- maximum visibility for your research: over $100 \mathrm{M}$ website views per year

At BMC, research is always in progress.

Learn more biomedcentral.com/submissions 